\title{
Enantiopure Planar Chiral and Chiral-at-Metal Iridacycles De- rived from Bulky Cobalt Sandwich Complexes
}

\author{
Ross A. Arthurs, Christopher C. Prior, David L. Hughes, Vasily S. Oganesyan and Christopher J. \\ Richards*
}

School of Chemistry, University of East Anglia, Norwich Research Park, Norwich, NR4 7TJ, U.K.

Supporting Information Placeholder

\begin{abstract}
Reaction of ( $\eta^{5}$-(S)-2-(4-methylethyl)oxazolinylcyclopentadienyl)( $\eta^{4}$-tetraphenylcyclobutadiene)cobalt with $\left[\mathrm{IrCp}^{*} \mathrm{Cl}_{2}\right]_{2}$ in acetonitrile with $\mathrm{KPF}_{6}$ and $\mathrm{KO} t$-Bu resulted in $S, S_{\mathrm{p}}, S_{\mathrm{Ir}}$ and $S, R_{\mathrm{p}}, R_{\mathrm{Ir}}$ configured acetonitrile and Cp* coordinated cationic iridacycles (d.r. up to $4.8: 1$ - kinetic control), the planar chiral configuration dictating the configuration of the pseudo-tetrahedral iridium-based stereogenic centre. Addition of water to the cycloiridation reaction resulted in an increase in yield (up to $78 \%$ ) at the cost of diastereoselectivity. Use of the corresponding substrate containing a $t$-Bu rather than an $i$-Pr substituted oxazoline gave exclusively the $S, S_{\mathrm{p}}, S_{\text {Ir }}$ diastereoisomer, and under the same conditions $(S)$-2-ferrocenyl-4-(1,1-dimethylethyl)oxazoline cycloiridated to give only the $S, S_{\mathrm{p}}, S_{\mathrm{Ir}}$ diastereoisomer. Substitution reactions of the title complexes at iridium proceeded with retention of configuration, a computational study revealing the proposed coordinatively unsaturated intermediate of a dissociative mechanism to display a relatively weak Co-Ir interaction, and a pronounced steric effect as the basis of stereocontrol.
\end{abstract}

\section{INTRODUCTION}

Late transition-metal derived metallacycles have been the subject of multiple studies, ${ }^{1}$ in part due to the use of these complexes as catalysts and precatalysts in synthesis. ${ }^{2}$ Much of this work has focused additionally on chiral non-racemic metallacycles, usually palladacycles, ${ }^{3}$ with these frequently derived from an auxiliary appended ferrocene precursor such as $(S)$-1. Following stereoselective $\mathrm{C}-\mathrm{H}$ activation, the resulting complex contains a new element of planar chirality. ${ }^{4}$ The use in this way of metals other than palladium is rare, and in light of this we recently reported the cycloiridation of ferrocenyloxazoline $(S)$-1 to give cationic complex $\left(S, S_{\mathrm{p}}, S_{\mathrm{Ir}}\right)$-2. This was formed as predominantly one of the four possible product diastereoisomers due to additional control of the iridium-based stereogenic center (Scheme 1). 5

Scheme 1. Diastereoselective cycloiridation of ferrocenyloxazoline $(S)-1 .{ }^{5}$

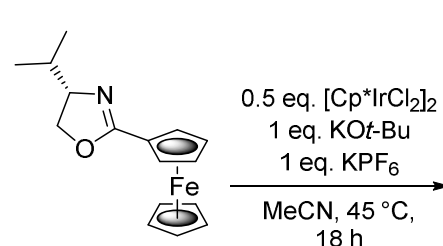

(S)-1

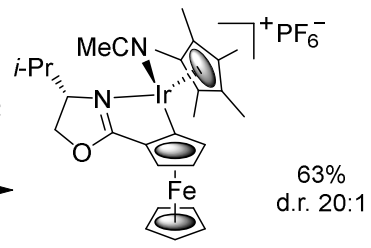

$\left(S, S_{\mathrm{p}}, S_{\mathrm{Ir}}\right)-\mathbf{2}$
Scheme 2. Diastereoselective cyclopalladation of cobalt oxazolines $(S)-3$ and $(S)-4{ }^{6}$

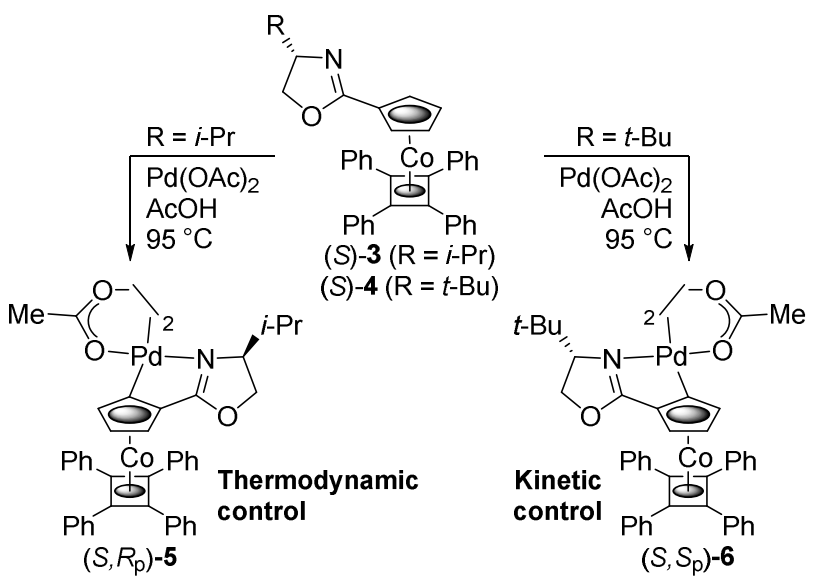

Substrates related to $(S)$-1, and also employed for the synthesis of planar chiral palladacycles, are oxazoline-appended cobalt sandwich complexes $(S)-3$ and $(S)-4$. The stereoselectivity observed is a function of the oxazoline $\mathrm{R}$ substituent, ${ }^{6}$ and also the reaction condition, ${ }^{7}$ such that $\left(S, R_{\mathrm{p}}\right)-\mathbf{5}$ and $\left(S, S_{\mathrm{p}}\right) \mathbf{- 6}$ may be obtained as a result of thermodynamic and kinetic control, respectively (Scheme 2). Palladacycle $\left(S, R_{\mathrm{p}}\right)-\mathbf{5}$ and its chloride bridged congener have been applied successfully as catalysts in asymmetric synthesis. ${ }^{8}$ Cycloplatination of $(S)-3$ has also been reported. ${ }^{9}$ 
In view of the ongoing interest in the application of iridacycles in catalysis, ${ }^{2 c, 2 d, 10}$ including asymmetric catalysis, ${ }^{11}$ we chose to explore the cycloiridation of $(S)-3$ and $(S)-\mathbf{4}$ with the aim of generating novel bulky iridacycles, ideally with control of the new elements of planar and metal-centered chirality. Our results are reported in this Article.

\section{RESULTS AND DISCUSSION}

The reaction conditions developed for the cycloiridation of ferrocene derivative $(S)$-1 (Scheme 1 ) were applied to cobalt oxazoline $(S)$-3 (Scheme 3, Table 1, entry 1). This resulted in a relatively low yield of two new complexes in a ratio of 3.7 $: 1$. The identity of both as iridacycles was established initially by there being two sets of three cyclopentadienyl hydrogen signals in the ${ }^{1} \mathrm{H}$ NMR spectrum recorded in $\mathrm{CD}_{3} \mathrm{CN}$ (major $=5.51,4.97$ and $4.82 \mathrm{ppm}$, minor $=5.12,4.94$ and $4.59 \mathrm{ppm}$ ), together with the corresponding two singlets of the $\mathrm{Cp}^{*}$ moiety $($ major $=1.70$, minor $=1.55 \mathrm{ppm}$ ). For both diastereoisomers a NOESY experiment revealed an NOE between the methyl substituents of the $\mathrm{Cp}^{*}$ group and the ortho-hydrogens of the phenyl groups attached to the $\eta^{4}$-cyclobutadiene moiety. This suggested that the diastereoisomers have different planar chiral configurations with the same relative iridium centred configuration. The identity of the major isomer as $\left(S, S_{\mathrm{p}}, S_{\mathrm{Ir}}\right)-7$ was supported by the observation of an NOE between one of the diastereotopic methyl groups of the iso-propyl oxazoline substituent and the meta-hydrogens of the phenyl groups. In addition, the negative chemical shift of this methyl group ($0.04 \mathrm{ppm}$ ) is further evidence of its proximity to the phenyl groups attached to the $\eta^{4}$-cyclobutadiene moiety. In contrast, the corresponding methyl groups of the minor diastereoisomer (0.99 and $0.69 \mathrm{ppm}$ ) do not reveal an NOE with the phenyl groups, from which it is assigned the identity $\left(S, R_{\mathrm{p}}, R_{\mathrm{Ir}}\right)-\mathbf{8}$. Additional circular dichroism and X-ray crystallographic studies confirmed these configurational assignments (vide infra).

Scheme 3. Diastereostereoselective cycloiridation of cobalt oxazoline $(S)-3$.

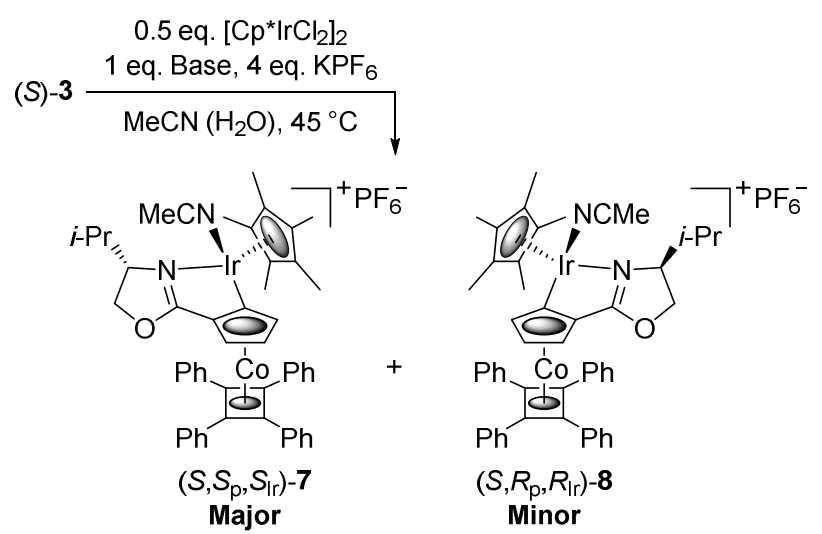

An attempt to separate the two diastereoisomers by chromatography on alumina was partially successful resulting in an enrichment of the major isomer. However, further purification of $\left(S, S_{\mathrm{p}}, S_{\mathrm{Ir}}\right)-7$ (an amorphous solid) by crystallisation did not prove possible. Chromatography also removed an unidentified brown substance (which displayed a very complex ${ }^{1} \mathrm{H}$ NMR spectrum), and it was found that the formation of this was avoided if a small quantity of water was added to the reaction. This gave an increase in yield although at the cost of diastereoselectivity (entry 2). This trend was also observed on increasing the reaction time from 18 hours to 7 days. The reaction in the absence of water resulted in a higher selectivity and lower yield (entry 3) compared to the corresponding reaction in the presence of water (entry 4). The former resulted in the highest selectivity observed $(4.8: 1)$, and the latter in the highest yield $(78 \%)$. In contrast the use as base of $\mathrm{NaOH}$, both with and without water, resulted in both lower selectivity and yield (entries 5 and 6). Thus $\mathrm{KOt}$-Bu is clearly the better base for this reaction, albeit that when used with water this leads to in situ generated hydroxide as an alternative base, and this may account for the lower selectivity observed under these conditions.

Table 1. Diastereostereoselective cycloiridation of cobalt oxazoline $(S)-3 .^{\mathrm{a}}$

\begin{tabular}{|c|c|c|c|c|c|}
\hline Entry & Base & $\mathrm{H}_{2} \mathrm{O}^{\mathrm{b}}$ & Time & $\begin{array}{l}\text { Ratio } \\
7: 8^{\text {c }}\end{array}$ & $\begin{array}{c}\text { Yield } \\
(\%)\end{array}$ \\
\hline 1 & $\begin{array}{c}\mathrm{KO} t- \\
\mathrm{Bu}\end{array}$ & No & $18 \mathrm{~h}$ & $3 \cdot 7: 1$ & 23 \\
\hline 2 & $\begin{array}{c}\mathrm{KO} t- \\
\mathrm{Bu}\end{array}$ & Yes & $18 \mathrm{~h}$ & $2.8: 1$ & 41 \\
\hline 3 & $\begin{array}{c}\mathrm{KO} t- \\
\mathrm{Bu}\end{array}$ & No & 7 days & $4.8: 1$ & 39 \\
\hline 4 & $\begin{array}{c}\mathrm{KO} t- \\
\mathrm{Bu}\end{array}$ & Yes & 7 days & $2.9: 1$ & 78 \\
\hline 5 & $\mathrm{NaOH}$ & No & 7 days & $1.6: 1$ & 19 \\
\hline 6 & $\mathrm{NaOH}$ & Yes & 7 days & 1 2.0 & 56 \\
\hline 7 & $\begin{array}{c}\mathrm{KO} t- \\
\mathrm{Bu}\end{array}$ & $\mathrm{No}^{\mathrm{d}}$ & 3 days & $1.5: 1$ & 35 \\
\hline
\end{tabular}

${ }^{a}(S)-3$ (o.012 $\mathrm{M}$ in $\mathrm{MeCN}$ ) at $45^{\circ} \mathrm{C}$ with o.5 eq. $\left[\mathrm{Cp}^{*} \mathrm{IrCl}_{2}\right]_{2}, 1$ eq. base, 4 eq. $\mathrm{KPF}_{6}{ }^{b}$ Approximately 9 eq. w. r. t. $(S)-3$. ${ }^{c}$ Determined by ${ }^{1} \mathrm{H}$ NMR spectroscopy, ${ }^{\mathrm{d}} \mathrm{D}_{2} \mathrm{O}$ added in place of $\mathrm{H}_{2} \mathrm{O}$.

The cycloiridation selectivity in favour of the $S_{\mathrm{p}}$ planar chiral configuration, together with the absence of any substantial change in the product ratio as a function of time, are suggestive of kinetic control of diastereoselectivity. To investigate this further cycloiridation was repeated as described in entry 2, excepting that $\mathrm{H}_{2} \mathrm{O}$ was replaced by $\mathrm{D}_{2} \mathrm{O}$ and the reaction time extended to 3 days (entry 7 ). This resulted in a similar outcome to entry 2 with no deuterium incorporation into the iridacycle products 7 or $\mathbf{8}$, in contrast to what would be expected for a reversible reaction under these conditions. The kinetic preference for $S_{\mathrm{p}}$ functionalisation is the same as that observed previously for the cyclopalladation of this substrate, ${ }^{6 c, 12}$ and the $\alpha$-lithiation, ${ }^{13}$ 
cyclopalladation $^{4}$ and cycloiridation 5 of related ferrocenyloxazoline $(S)$-1.

With the aim of improving the cycloiridation stereoselectivity, the reaction was performed on the corresponding $(S)$-tert-leucinol derived oxazoline $(S)$-4. Application of the conditions that resulted in the highest yield with $(S)-3$ (Table 1 , entry 4 ) in this instance, resulted in a slow reaction and formation of the product iridacycle as a single diastereoisomer (Scheme 4). The use of a NOESY experiment for the preliminary determination of the stereochemistry proved inconclusive. Instead, the similarity of the circular dichroism spectrum to that of $\left(S, S_{\mathrm{p}}, S_{\mathrm{Ir}}\right)-7$ was used to assign the configuration of the new iridacycle as $\left(S, S_{\mathrm{p}}, S_{\mathrm{Ir}}\right)$-9 (Figure 1). ${ }^{14}$

Scheme 4. Diastereostereoselective cycloiridation of cobalt oxazoline $(S)-4$.
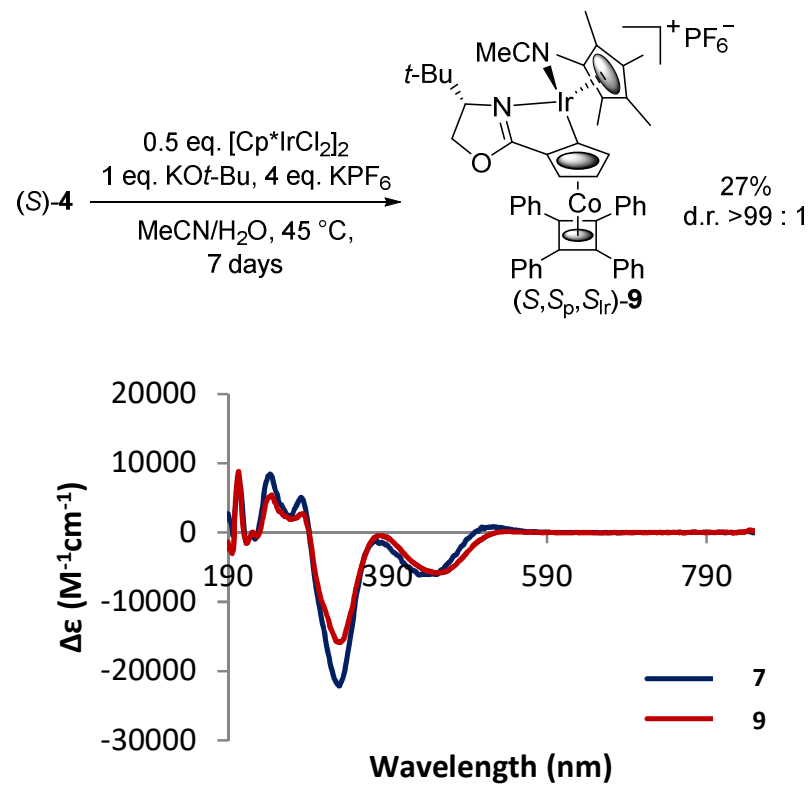

Figure 1. Circular dichroism spectra of $\left(S, S_{\mathrm{p}}, S_{\mathrm{Ir}}\right)-7$ (4: 1 d.r. with $S, R_{\mathrm{p}}, R_{\mathrm{Ir}}$ isomer) and $\left(S, S_{\mathrm{p}}, S_{\mathrm{Ir}}\right)-\mathbf{9}$.

The significantly higher diastereoselectivity observed with the tert-butyl substituted cobalt oxazoline $(S)$-4 prompted us to examine the cycloiridation of corresponding ferrocenyloxazoline $(S)$-10. Use of the standard conditions with an 18 hour reaction time in the absence of water gave a new iridacycle as a single diastereoisomer (Scheme 5). With addition of water the diastereoselectivity was not compromised and the yield increased from $29 \%$ to $45 \%$. The identity of the new iridacycle derived from $(S)$-10 as $\left(S, S_{\mathrm{p}}, S_{\mathrm{Ir}}\right)$-11 was established by the similarity of aspects of its ${ }^{1} \mathrm{H}$ NMR spectrum to that of $\left(S, S_{\mathrm{p}}, S_{\mathrm{Ir}}\right)$-2, together with a NOESY experiment revealing cross-peaks between the unsubstituted $\mathrm{Cp}$ group and the $t$ - $\mathrm{Bu}$ and $\mathrm{Cp}^{*}$ methyl substituents. In addition, the circular dichroism spectra of $\left(S, S_{\mathrm{p}}, S_{\mathrm{Ir}}\right)$-2 and $\left(S, S_{\mathrm{p}}, S_{\mathrm{Ir}}\right)$-11 are essentially identical (Figure 2).
Scheme 5. Diastereostereoselective cycloiridation of ferrocenyloxazoline $(S)$-10.
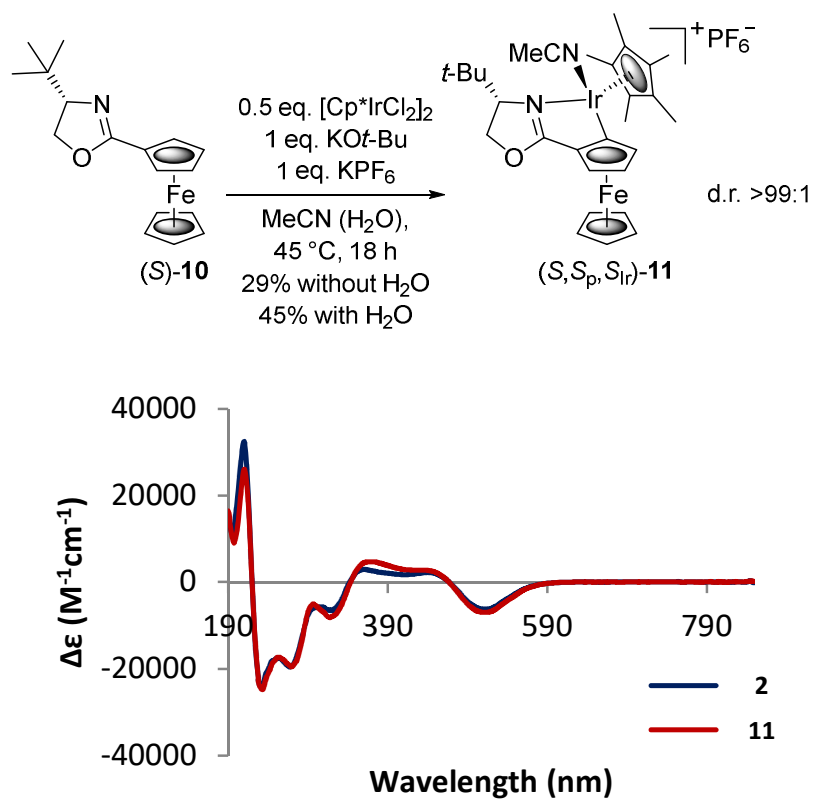

Figure 2. Circular dichroism spectra of $\left(S, S_{\mathrm{p}}, S_{\mathrm{Ir}}\right)-2$ ( $48: 1$ d.r. with $S, R_{\mathrm{p}}, R_{\mathrm{Ir}}$ isomer $)$ and $\left(S, S_{\mathrm{p}}, S_{\mathrm{Ir}}\right)-\mathbf{1 1}$.

In light of the influence of added water on the outcome of cycloiridation, we revisited this reaction with substrate $(S)$-1 (Scheme 1). In our previous study acetonitrile was dried over molecular sieves, and for this study acetonitrile was distilled from $\mathrm{CaH}_{2}$ under argon immediately prior to use. With the solvent dried in this way, and using the same conditions as described in Scheme 5, cycloiridation of $(S)$ $\mathbf{1}$ again resulted predominantly in $\left(S, S_{\mathrm{p}}, S_{\mathrm{Ir}}\right)$-2, with an increase in diastereoselectivity (d.r. $=48: 1,38 \%$ yield). In the presence of added water the diastereoselectivity decreased (d.r. $=14: 1,31 \%$ yield). Thus, as in the cobalt series, the diastereoselectivity of cycloiridation controlled by the isopropyl oxazoline auxiliary is maximised by the exclusion of water. In contrast, with the tert-butyl oxazoline auxiliary, complete control of diastereoselectivity results in both the iron and cobalt series irrespective of the presence of water.

A previously observed feature of the chemistry of ferrocene derived iridacycles is the formation of a substituted pentamethyliridocenium cation from these on heating. ${ }^{15}$ That a cobalt iridacycle can also undergo this transformation was established by heating a mixture of $\left(S, S_{\mathrm{p}}, S_{\mathrm{Ir}}\right)$-7 and $\left(S, R_{\mathrm{p}}, R_{\mathrm{Ir}}\right)-\mathbf{8}$ in deuterated acetonitrile, and monitoring the reaction daily by ${ }^{1} \mathrm{H}$ NMR spectroscopy (Scheme 6 Path A). After 8 days this revealed the complete transformation of the iridacycles into the known iridocenium cation $(S)$-12 (obtained previously from $\left.\left(S, S_{\mathrm{p}}, S_{\mathrm{Ir}}\right)-\mathbf{2}^{15}\right)$. The relative stability of the cobalt compared to the iron based iridacycles was determined by heating together a $1.4: 1$ mixture of $\left(S, S_{\mathrm{p}}, S_{\mathrm{Ir}}\right)-\mathbf{9}$ and $\left(S, S_{\mathrm{p}}, S_{\mathrm{Ir}}\right)-\mathbf{1 1}$ in acetonitrile. After 8 days at $45{ }^{\circ} \mathrm{C}$ examination of the crude reaction mixture by 
${ }^{1} \mathrm{H}$ NMR spectroscopy revealed unreacted cobalt iridacycle $\left(S, S_{\mathrm{p}}, S_{\mathrm{Ir}}\right)$-9 and new iridocenium cation $(S)$-14 (Scheme 6 Path B). The latter was purified by chromatography on alumina.

Further examination of these reactions revealed the formation of an organic by-product, and from the first of these (Path A) this was isolated and identified by an X-ray crystallographic study as $(Z)$-enedione 13, an oxidation product of the tetraphenylcyclobutadiene moiety (see supporting information). This outcome fits with our occasional obsevation of the formation of an iridocenium ion byproduct from the cycloiridation reactions described above. This could be prevented if rigourous care was taken to exclude oxygen.

Scheme 6. Transformation (Path A) and competitive transformation (Path B) of iridacycles into iridocenium cations.

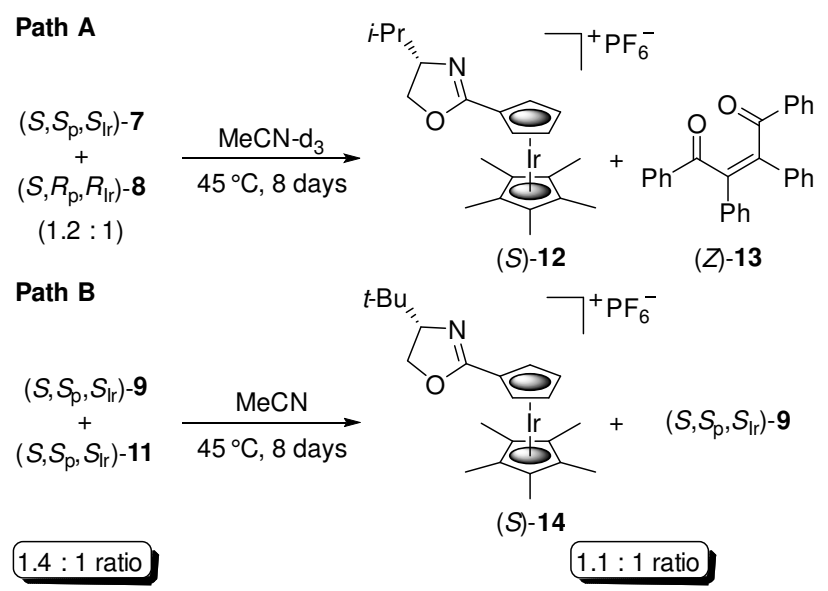

An alternative method for the cycloiridation of $(S)$-1 with $\left[\mathrm{IrCp}{ }^{*} \mathrm{Cl}_{2}\right]_{2}$ used sodium acetate as base in dichloromethane. This reaction resulted in the poorly selective formation of two neutral chloride ligated diastereoisomers with different planar chiral configurations. ${ }^{5}$ Repetition of these and related conditions with cobalt oxazoline $(S)-3$ as substrate was unsuccessful and led only to the recovery of starting material. Instead, neutral chloride ligated diaststereoisomers were obtained starting with an orange mixture of $\left(S, S_{\mathrm{p}}, S_{\mathrm{Ir}}\right)-7$ and $\left(S, R_{\mathrm{p}}, R_{\mathrm{Ir}}\right)-\mathbf{8}$, addition of dichloromethane to give a brown/green solution, and further addition of tetrabutylammonium chloride (TBAC) resulting in an instantaneous change in colour back to orange (Scheme 7). Alternatively, chloride ligand substitution resulted from the addition of $\mathrm{KCl}$ to a solution of $\left(S, S_{\mathrm{p}}, S_{\mathrm{Ir}}\right)-7$ and $\left(S, R_{\mathrm{p}}, R_{\mathrm{Ir}}\right)-\mathbf{8}$ in methanol. Irrespective of the deuterated solvent used $\left(\mathrm{CDCl}_{3}\right.$, THF- $\mathrm{d}_{8}$ or acetone- $\left.\mathrm{d}_{6}\right)$ the NMR spectrum of the material obtained after work up from both reactions was broad, precluding product identification. Prolonged standing of a $\mathrm{CDCl}_{3}$ solution of the product (from $\mathrm{MeOH} / \mathrm{KCl}$ ) resulted in the isolation of two crystal forms; the more abundant were pink/orange rectangular prisms, and the less abundant were much smaller pale pink thin prisms.

Scheme 7. Stereospecific ligand exchange via chlorides $\left(S, S_{\mathrm{p}}, R_{\mathrm{Ir}}\right)-15$ and $\left(S, R_{\mathrm{p}}, S_{\mathrm{Ir}}\right)-16$.
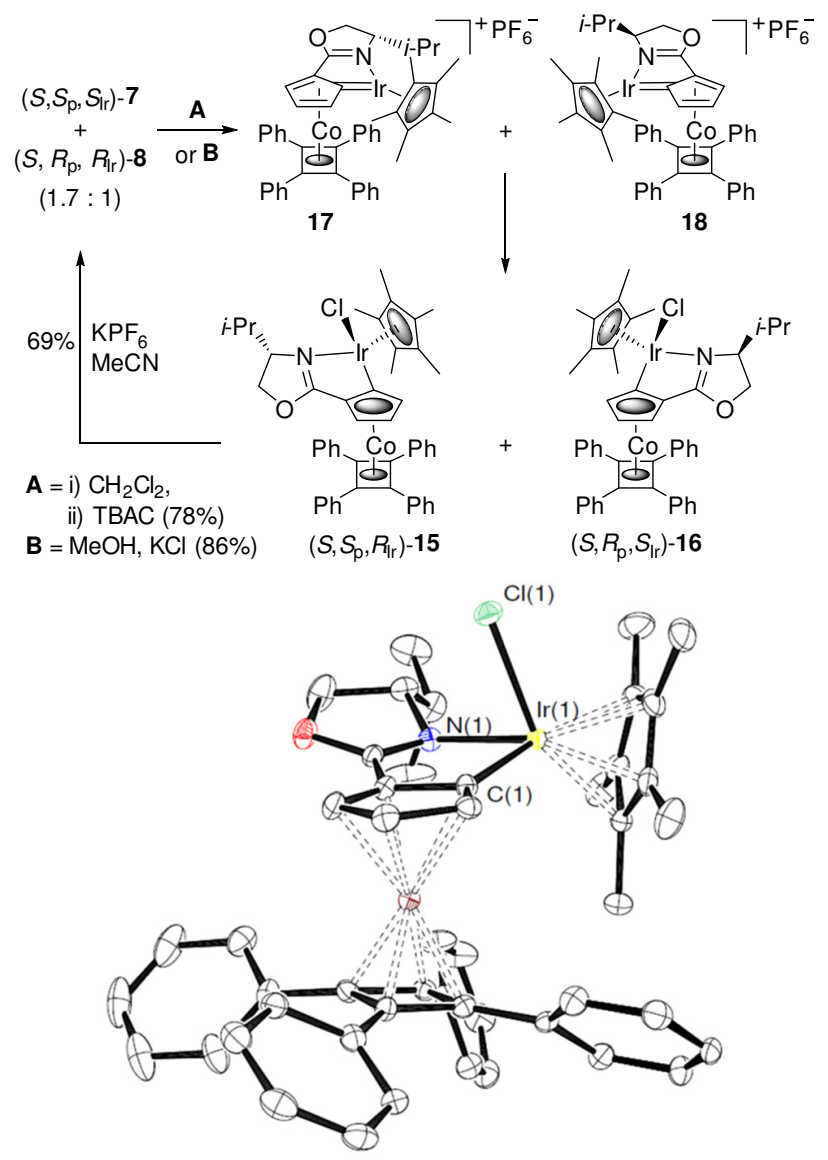

Figure 3. A representation of the crystal structure of $\left(S, S_{\mathrm{P}}, R_{\mathrm{Ir}}\right)-\mathbf{1 5}$ (hydrogen atoms omitted for clarity). Principal bond dimensions $\left[\AA\right.$ and $\left.{ }^{\circ}\right]$ include: Ir-C(1) 2.053(4), Ir-N(1) 2.129(4), Ir-Cl 2.4274(11), Ir-Ct3 (centroid of Cp*) 1.819; N(1)-IrC(1) 77.95(16), Cl-Ir-C(1) 85.99(13), Cl-Ir-N(1) 79.72(11), N(1)-Ir$\mathrm{Ct}_{3}$ 138.67, C(1)-Ir-Ct3 132.90. Flack parameter $=-0.022(4)$.

Single crystal X-ray diffraction analysis of the former revealed the structure to be $\left(S, S_{\mathrm{p}}, R_{\mathrm{Ir}}\right)$-15 (Figure 3 ), and the same analysis of the latter revealed the structure to be $\left(S, R_{\mathrm{p}}, S_{\mathrm{Ir}}\right)$-16 (Figure 4$)$. In both structures a $\mathrm{Cp}^{*}$ methyl group is proximate to two phenyl groups, in agreement with the NOE's observed for the acetonitrile coordinated precursors (shortest methyl carbon to ortho carbon distance $=3.430 \AA$ for $\left(S, S_{\mathrm{p}}, R_{\mathrm{Ir}}\right)-\mathbf{1 5}$ and $3.439 \AA$ for $\left.\left(S, R_{\mathrm{p}}, S_{\mathrm{Ir}}\right)-\mathbf{1 6}\right)$. In addition, the former structure displays an iso-propyl methyl carbon to meta-phenyl carbon distance of $3.619 \AA$ in agreement with the NOE observed between the hydrogens attached to these carbons in acetonitrile coordinated precursor $\left(S, S_{\mathrm{p}}, S_{\mathrm{Ir}}\right)-7$. 


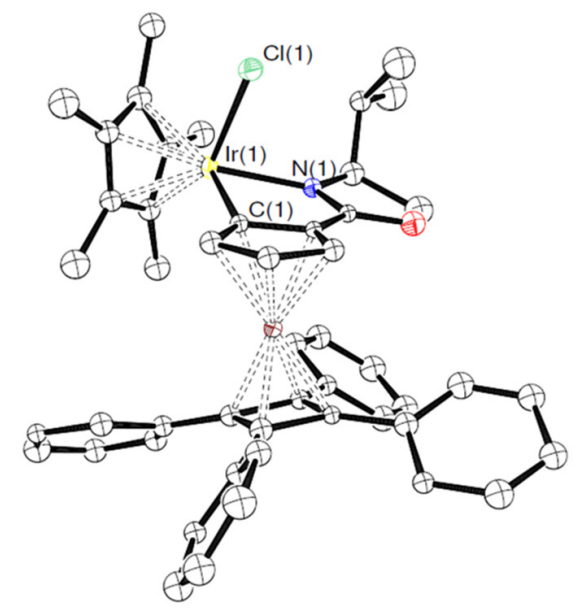

Figure 4. A representation of the structure of one of the two independent molecules of $\left(S, R_{\mathrm{p}}, S_{\mathrm{Ir}}\right)-\mathbf{1 6}$. Principal bond lengths $[\AA]$ include: $\operatorname{Ir}(1)-\mathrm{C}(1)=2.08(3), \operatorname{Ir}(1)-\mathrm{N}(1)=2.13(2), \operatorname{Ir}(1)-\mathrm{Cl}(1)=$ $2.414(8), \operatorname{Ir}(1)-\mathrm{Cp}^{*}$ (centre of mass) $=1.81$. Principal bond angles [ ${ }^{\circ}$ ] include: $\mathrm{N}(1)-\operatorname{Ir}(1)-\mathrm{C}(1)=76.7(10), \mathrm{Cl}(1)-\operatorname{Ir}(1)-\mathrm{C}(1)=$ 82.8(8), $\mathrm{Cl}(1)-\operatorname{Ir}(1)-\mathrm{N}(1)=85.4(6), \mathrm{N}(1)-\operatorname{Ir}(1)-\mathrm{Cp}^{*}=137.3, \mathrm{C}(1)-$ $\operatorname{Ir}(1)-C \mathrm{p}^{*}=136.5$. Flack parameter $=0.036(7)$.

Treatment of the chloride ligated iridacycles $\left(S, S_{\mathrm{p}}, R_{\mathrm{Ir}}\right)-\mathbf{1 5}$ and $\left(S, R_{\mathrm{p}}, S_{\text {Ir }}\right)-\mathbf{1 6}$ with potassium hexafluorophosphate in acetonitrile resulted in reformation of $\left(S, S_{\mathrm{p}}, S_{\mathrm{Ir}}\right)-7$ and $\left(S, R_{\mathrm{p}}, R_{\mathrm{Ir}}\right)$-8 with no change in the ratio of diastereoisomers. Substitution at iridium was further investigated by dissolution of a $2: 1$ ratio of $\left(S, S_{\mathrm{p}}, S_{\mathrm{Ir}}\right)-7 /\left(S, R_{\mathrm{p}}, R_{\mathrm{Ir}}\right)-\mathbf{8}$ in dichloromethane followed by addition of triphenylphosphine (Scheme 8), and this again resulted in an instantaneous change in the colour of the solution from brown/green to orange. New phosphine adducts were formed in a $2: 1$ ratio as determined by both ${ }^{31} \mathrm{P}$ and ${ }^{1} \mathrm{H} N \mathrm{NMR}$ spectroscopy. A NOESY experiment revealed, for both isomers, an NOE between the methyl substituents of the $\mathrm{Cp}^{*}$ group and the ortho-hydrogens of the cyclobutadiene attached phenyl groups, and for the major isomer an NOE between one of the methyl groups of the iso-propyl oxazoline substituent (o.43 ppm) and the cyclobutadiene attached phenyl groups. In addition, the minor isomer displayed an NOE between one of the methyl groups of the iso-propyl oxazoline substituent $(0.21 \mathrm{ppm})$ and the phosphorous attached phenyl groups. On the basis of the above observations the major and minor isomers are identified as $\left(S, S_{\mathrm{p}}, R_{\mathrm{Ir}}\right)$-19 and $\left(S, R_{\mathrm{p}}, S_{\mathrm{Ir}}\right)$-20, and the outcome of the reaction sequence is consistent with substitution occurring with retention of configuration via configurationally stable and coordinatively unsaturated cationic intermediates 17 and 18. Stereospecific substitution in this way is the same as established previously in ferrocene iridacycles ${ }^{5}$ and also reported for racemic ( $\eta^{6}$-arene)tricarbonylchromium iridacycles. ${ }^{16}$

Scheme 8. Stereospecific triphenylphosphine substitution at iridium.

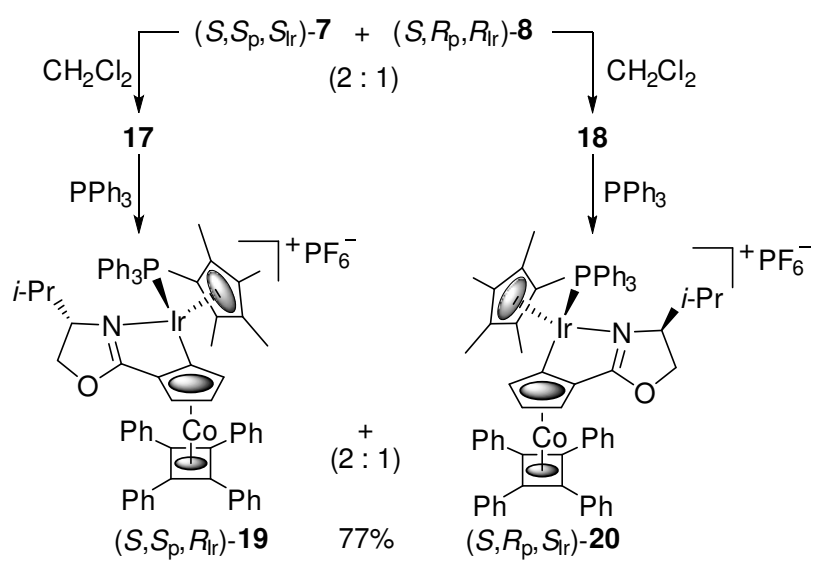

A computational study was undertaken to determine the relative energy of iridacycle diastereoisomers with different planar chiral or chiral-at-iridium configurations. Starting with the molecular geometry of $\left(S, S_{\mathrm{p}}, R_{\mathrm{Ir}}\right)-\mathbf{1 5}$ and $\left(S, R_{\mathrm{p}}, S_{\mathrm{Ir}}\right)$-16 (as determined by $\mathrm{X}$-ray crystal structure analysis) the structures were optimised using the TPSS functional and the dispersion corrected B97D functional with the Gaussian 09 set of programs.$^{17}$ Iridium, cobalt and chlorine atoms were described using the LANL2DZ basis set and effective core potential, ${ }^{18}$ with all other atoms being described with the all electron $6-31+G^{* *}$ basis set., ${ }^{, 19}$ Stationary points for all structures were confirmed as minima by frequency analysis. The chiral-at-iridium diastereoisomers $\left(S, S_{\mathrm{p}}, S_{\mathrm{Ir}}\right)$-21 and $\left(S, R_{\mathrm{p}}, R_{\mathrm{Ir}}\right)$-22 (Figure 5$)$ were modeled similarly, together with coordinatively unsaturated iridium complexes $\mathbf{1 7}$ and $\mathbf{1 8}$. Key data from these studies are presented in Tables 2-4. The trends in relative energy are the same for both the TPSS and B97D sets of calculations (Table 2), but the bond distances etc determined by the former are in better agreement with those determined by X-ray crystal structure analyses, such that the TPSS data are used in Tables 3 and 4, and in the following discussion.

Comparison of diastereoisomers $\left(S, S_{\mathrm{p}}, R_{\mathrm{Ir}}\right)-\mathbf{1 5}$ and $\left(S, S_{\mathrm{p}}, S_{\mathrm{Ir}}\right)$-21 reveals that the former is more stable than the latter by $2.19 \mathrm{kcal} / \mathrm{mol}^{-1}$ (Figure 6a). This difference is attributed, at least in part, to an electrostatic repulsion between the chlorine ligand and the $\pi$-system of the phenyl groups. ${ }^{20}$ That the $C \mathrm{p}^{*}$ group is oriented towards the phenyl groups in $\left(S, S_{\mathrm{p}}, R_{\mathrm{Ir}}\right)-\mathbf{1 5}$ is therefore not disfavoured, as a $\mathrm{Cp}^{*}$ methyl group is accommodated between two phenyl groups without a destabilising interaction (Figures 3 and 6a). 
Table 2. Relative energies of the iridacycle complexes. ${ }^{\mathrm{a}}$

\begin{tabular}{|c|c|c|c|c|c|c|}
\hline Energy & $\left(S, S_{\mathrm{p}}, R_{\mathrm{Ir}}\right)-\mathbf{1} \mathbf{5}^{\mathrm{b}}$ & $\left(S, S_{\mathrm{p}}, S_{\text {Ir }}\right)-\mathbf{2 1}$ & $\left(S, R_{\mathrm{p}}, S_{\text {Ir }}\right)-\mathbf{1 6}$ & $\left(S, R_{\mathrm{p}}, R_{\mathrm{Ir}}\right)-\mathbf{2 2}{ }^{\mathrm{b}}$ & $\mathbf{1 7}^{\mathrm{c}}$ & $\mathbf{1 8}$ \\
\hline TPSS & 2.59 & 4.78 & $\mathrm{o}$ & 1.38 & 1.53 & $\mathbf{0}$ \\
\hline B97D & 6.64 & 8.87 & 0 & 4.91 & 3.94 & 0 \\
\hline
\end{tabular}

${ }^{\mathrm{a}} \mathrm{kcal} \mathrm{mol}{ }^{-1}$. ${ }^{\mathrm{b}}$ Relative to $\left(S, R_{\mathrm{p}}, S_{\mathrm{Ir}}\right)-\mathbf{1 6}$. ${ }^{\mathrm{c}}$ Relative to $\mathbf{1 8}$.

Table 3. Selected bond lengths and bond angles of the computed iridacycle complexes (TPSS).

\begin{tabular}{|c|c|c|c|c|c|c|}
\hline Parameter $^{\mathrm{a}}$ & $\left(S, S_{\mathrm{p}}, R_{\mathrm{Ir}}\right)-\mathbf{1 5}$ & $\left(S, S_{\mathrm{p}}, S_{\mathrm{Ir}}\right)-\mathbf{2 1}$ & $\left(S, R_{\mathrm{p}}, S_{\mathrm{Ir}}\right)-\mathbf{1 6}$ & $\left(S, R_{\mathrm{p}}, R_{\mathrm{Ir}}\right)-\mathbf{2 2}$ & $\mathbf{1 7}$ & $\mathbf{1 8}$ \\
\hline $\mathrm{Ir}-\mathrm{Co}$ & 4.087 & 4.033 & 4.026 & 4.042 & 3.850 & 3.814 \\
\hline $\mathrm{Ir}-\mathrm{Cl}$ & 2.522 & 2.493 & 2.523 & 2.497 & $\mathrm{n} / \mathrm{a}$ & $\mathrm{n} / \mathrm{a}$ \\
\hline $\mathrm{Ir}-\mathrm{N}$ & 2.134 & 2.128 & 2.124 & 2.146 & 2.079 & 2.081 \\
\hline $\mathrm{Ir}-\mathrm{C}(\mathrm{CpCo})$ & 2.053 & 2.053 & 2.059 & 2.055 & 2.030 & 2.030 \\
\hline $\mathrm{Ir}-\mathrm{Cp}^{* \mathrm{~b}}$ & 1.841 & 1.842 & 1.839 & 1.837 & 1.829 & 1.829 \\
\hline $\mathrm{N}-\mathrm{Ir}-\mathrm{Cp}^{* \mathrm{~b}}$ & 139.08 & 133.55 & 137.47 & 136.97 & 140.76 & 142.39 \\
\hline $\mathrm{C}-\mathrm{Ir}-\mathrm{Cp}^{* \mathrm{~b}}$ & 136.08 & 131.35 & 137.05 & 128.61 & 138.97 & 138.52 \\
\hline
\end{tabular}

${ }^{\text {a Distances }[\AA ̊]}$; angles $\left[^{\circ}\right] .{ }^{\mathrm{b}}$ To the centre of mass of the $\eta^{5}$-ligand.

Table 4. Selected Mulliken partial charges of the computed iridacycle complexes (TPSS).

\begin{tabular}{|c|c|c|c|c|c|c|}
\hline Atom & $\left(S, S_{\mathrm{p}}, R_{\mathrm{Ir}}\right)-\mathbf{1 5}$ & $\left(S, S_{\mathrm{p}}, S_{\mathrm{Ir}}\right)-\mathbf{2 1}$ & $\left(S, R_{\mathrm{p}}, S_{\mathrm{Ir}}\right)-\mathbf{1 6}$ & $\left(S, R_{\mathrm{p}}, R_{\mathrm{Ir}}\right)-\mathbf{2 2}$ & $\mathbf{1 7}$ & $\mathbf{1 8}$ \\
\hline $\mathrm{Ir}$ & 0.503 & 0.405 & 0.528 & 0.495 & 1.811 & 1.747 \\
\hline Co & -0.125 & -0.311 & -0.185 & -0.012 & -0.101 & -0.321 \\
\hline $\mathrm{N}$ & 0.435 & 0.472 & 0.547 & 0.583 & 0.123 & 0.271 \\
\hline
\end{tabular}

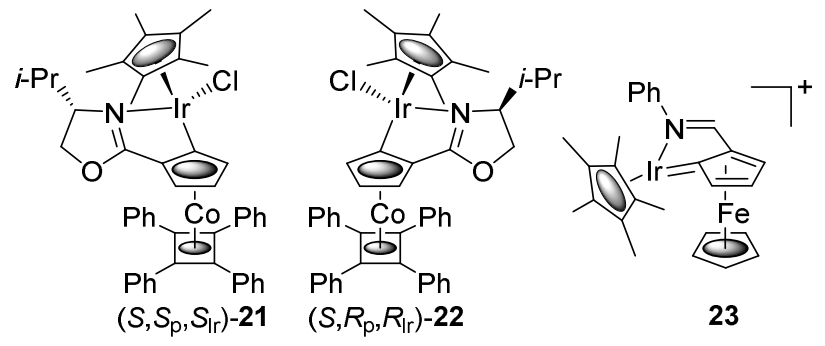

Figure 5. Alternative chiral-at-iridium diastereoisomers $\left.S, S_{\mathrm{p}}, S_{\mathrm{Ir}}\right)$-21 and $\left(S, R_{\mathrm{p}}, R_{\mathrm{Ir}}\right)-\mathbf{2 2}$, and ferrocene-based cationic iridacycle 23.
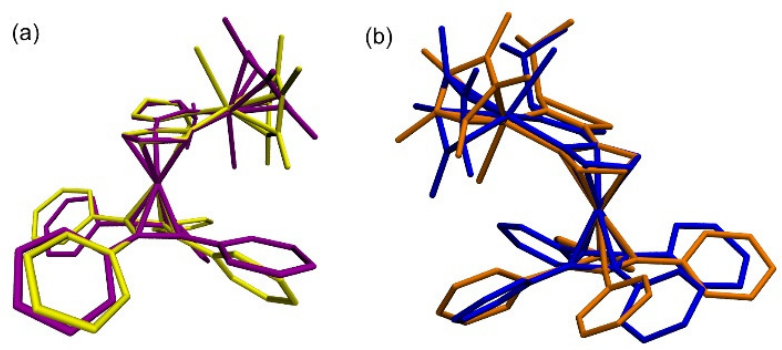

Figure 6. Overlays of (a) the minimised structures of $\left.S, S_{\mathrm{p}}, R_{\mathrm{Ir}}\right)$ 15 (yellow) and $\left.S, S_{\mathrm{p}}, S_{\text {Ir }}\right)-\mathbf{2 1}$ (purple) and (b) $\left(S, R_{\mathrm{p}}, S_{\text {Ir }}\right)-\mathbf{1 6}$ (blue) and $\left(S, R_{\mathrm{p}}, R_{\mathrm{Ir}}\right)-\mathbf{2 2}$ (orange).
For diastereoisomers $\left(S, R_{\mathrm{p}}, S_{\mathrm{Ir}}\right)-\mathbf{1 6}$ and $\left(S, R_{\mathrm{p}}, R_{\mathrm{Ir}}\right)$-22 the total energy calculations reveal the former to be more stable than the latter by $1.38 \mathrm{kcal} \mathrm{mol}^{-1}$ (Figure 6b), again potentially a consequence of a destabilising phenylchlorine interaction. Comparison of the two more stable chiral-at-iridium diastereoisomers reveals $\left(S, R_{\mathrm{p}}, S_{\mathrm{Ir}}\right)-\mathbf{1 6}$ to be more stable than $\left(S, S_{\mathrm{p}}, R_{\mathrm{Ir}}\right)-\mathbf{1 5}$ by $2.59 \mathrm{kcal} \mathrm{mol}^{-1}$, a consequence of the oxazoline iso-propyl substituent being oriented away rather than towards the phenyl groups. This further supports the kinetic basis of the planar-chiral selectivity, as the acetonitrile ligated congener of $\left(S, S_{\mathrm{p}}, R_{\mathrm{Ir}}\right)$ $\mathbf{1 5}$ is the major diastereoisomer formed on cycloiridation.

Calculated cationic complexes $\mathbf{1 7}$ and $\mathbf{1 8}$ both display a shorter Ir-Co distance than observed and calculated for the chloride adducts, but the difference $(\sim 0.22 \AA=5.3 \%)$ is markedly less than the calculated reduction in Ir-Fe distance resulting from the conversion of a related ferrocene-based iridacycle into cationic intermediate 23 on loss the chloride ligand ( $0.61 \AA=15.7 \%) .{ }^{5}$ In the ferrocene series the Fe-Ir interaction in the cation is also manifest in a decrease in the partial Mulliken charge on iron, and in a tilt of iridium towards iron of $\sim 21^{\circ}$ (relative to the planar cyclopentadienyl ring). In contrast, complexes 17 and 18 do not display a reduction of Mulliken partial charge on Co, and there is a tilt of iridium away from cobalt $\left(\sim 9-10^{\circ}\right)$. 
These differences are apparent on comparison of the structure overlay of cations 18 and 23 (Figure $7 a$ ). For 18, comparison of the corresponding DFT calculated structure with methyl groups in place of phenyl groups reveals a shorter Ir-Co distance (3.739 $\AA$ ) and a Ir-C(CpCo) bond essentially in the plane of the cyclopentadienyl group (Figure 7b). Thus Co-Ir interaction is inherently less than Fe-Ir interaction in coordinatively unsaturated cationic complexes, a difference exacerbated by the presence of phenyl groups. The small Co-Ir interaction also contrasts with the significant shortening of the $\mathrm{Cr}$-Ir distance calculated for the cationic complex formed on loss of a chloride ligand from a Cp-substituted ( $\eta^{6}-$ arene)tricarbonylchromium iridacycle $(\sim 1.1 \AA$, $27 \%){ }^{16}$

As stereospecific substitution of the cobalt sandwich complexes at iridium is not so clearly a stereoelectronic effect, as is the case with the corresponding ferrocene and ( $\eta^{6}$-arene)tricarbonylchromium complexes, it may alternatively result from steric shielding of iridium by the phenyl groups attached to the cyclobutadiene moiety. Either way, inversion at iridium on substitution is kinetically inaccessible, and in the case of chloride substitution at least, thermodynamically disfavoured based on calculations.
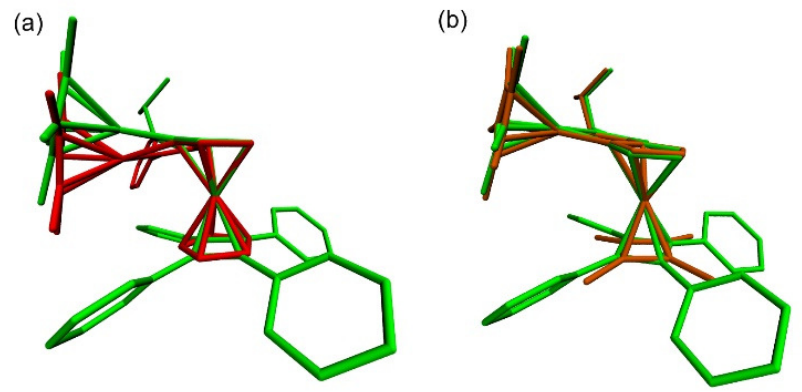

Figure 7. Overlays of (a) the minimised structures of cobaltbased cationic iridacycle $\mathbf{1 8}$ (green) with iron-based cationic iridacycle $\mathbf{2 3}$ (red), and (b) $\mathbf{1 8}$ (green) with its methyl in place of phenyl analogue (orange).

\section{CONCLUSION}

Oxazoline appended bulky cobalt-based sandwich complexes are suitable substrates for cycloiridation. Use of a (S)-tert-leucine derived auxiliary gives a single diastereoisomer; the new $S_{\mathrm{p}}$-element of planar chirality is a result of kinetic control, and in the new element of iridium-centered chirality the exchangeable ligand is oriented away from the sandwich complex. Dissociative substitution of this exchangeable ligand proceeds with complete retention of configuration. Although these outcomes are as observed previously in related ferrocenebased chemistry, a computational study reveals that in the cationic intermediate (resulting from ligand dissociation), there is significantly less Co-Ir interaction compared to the previously computed Fe-Ir interaction. Furthermore, compared to the ferrocene-based complexes, the cobaltbased iridacycles are much less prone to transform into iridocenium complexes, and the environment about iridium is markedly more crowded due to the proximity of one or more phenyl groups. The significance of these differences with respect to the use of these chiral nonracemic iridacycle complexes in catalysis is under investigation.

\section{EXPERIMENTAL SECTION}

General remarks. Acetonitrile and dichloromethane were dried by distillation from calcium hydride. Methanol was dried over $4 \AA$ molecular sieves. All cycloiridation reactions and reactions involving the use of dry solvents were carried out under an inert atmosphere of either nitrogen or argon. Silica gel (6o Å pore size, $40-63 \mu \mathrm{m}$ technical grade) and neutral aluminium oxide (Brockmann I, $50-200 \mu \mathrm{m}$ ) were used for chromatography.

General procedure for cycloiridation. The oxazoline (o.o6 $\mathrm{mmol}$ ), (pentamethylcyclopentadienyl)iridium(III) chloride dimer (0.025 g, $0.03 \mathrm{mmol}$ ), potassium tert-butoxide ( $0.007 \mathrm{~g}$, $0.06 \mathrm{mmol}$ ) and potassium hexafluorophosphate (0.047 g, 0.25 $\mathrm{mmol}$ ) were added to a flame dried Schlenk tube under an inert atmosphere (glove box). After the addition of freshly distilled acetonitrile $(5 \mathrm{~mL})$ and water (1o $\mu \mathrm{L})$, the mixture was stirred at $45{ }^{\circ} \mathrm{C}$ for the specified time. The reaction was allowed to cool to room temperature and washed with hexane until the hexane layer became colourless. The acetonitrile layer was reduced in vacuo and the resulting solid was re-dissolved in a minimum amount of acetonitrile and filtered through a short pad of neutral alumina using acetonitrile as the eluent to give a bright orange solution, followed by removal of the solvent in vacuo.

Synthesis of $\left(S, S_{\mathrm{p}}, S_{\mathrm{Ir}}\right)-7 \&\left(S, \boldsymbol{R}_{\mathrm{p}}, \boldsymbol{R}_{\mathrm{Ir}}\right)-8$ (d.r. $\left.4.8: 1\right)$. $\left(\eta^{5-}(S)-2-\left(4^{-}\right.\right.$ Methylethyl)oxazolinylcyclopentadienyl)-( $\eta^{4-}$

tetraphenylcyclobutadiene)cobalt ${ }^{6 a}(0.037 \mathrm{~g}, 0.06 \mathrm{mmol})$ was cycloiridated using the general procedure with a reaction time of 7 days to yield the product as an amorphous orange solid ( $0.03 \mathrm{~g}$, $39 \%)$. NMR data is for major diastereoisomer: Mp: $138-140{ }^{\circ} \mathrm{C}$. $[\alpha]_{D^{23}}{ }^{\circ} \mathrm{C}=-640$ (c o.2, MeCN). IR (film): 3058, 2967, 2923, 1600 $(\mathrm{C}=\mathrm{N}), 842 .{ }^{1} \mathrm{H}$ NMR $\left(500 \mathrm{MHz}, \mathrm{MeCN}-\mathrm{d}^{3}\right): 7.51-7.48(8 \mathrm{H}, \mathrm{m}$, $\mathrm{Ar} H), 7.30-7.22(12 \mathrm{H}, \mathrm{m}, \mathrm{ArH}), 5.50\left(1 \mathrm{H}, \mathrm{dd}, 3 J_{\mathrm{HH}}=2.2,4 \mathrm{~J}_{\mathrm{HH}}=1.0\right.$ $\mathrm{Hz}, \mathrm{CpH}), 4.97\left(\mathrm{lH}, \mathrm{dd}, 3_{\mathrm{HH}}=2.6,{ }^{4} J_{\mathrm{HH}}=1.0 \mathrm{~Hz}, \mathrm{CpH}\right), 4.82(\mathrm{1H}$, apt, $\left.{ }^{3} J_{\mathrm{HH}}=2.5 \mathrm{~Hz}, \mathrm{CpH}\right), 4.65\left(1 \mathrm{H}, \mathrm{dd},{ }^{2} J_{\mathrm{HH}}=10.1,{ }^{3} J_{\mathrm{HH}}=9.1 \mathrm{~Hz}\right.$, $\mathrm{CHH}), 4.36\left(1 \mathrm{H}, \mathrm{apt},{ }^{2} J_{\mathrm{HH}}=8.6 \mathrm{~Hz}, \mathrm{CHH}\right), 3.90\left(1 \mathrm{H}, \mathrm{ddd}, 3 J_{\mathrm{HH}}=\right.$ $\left.10.2,3_{\mathrm{HH}}=8.3,{ }^{3} \mathrm{JHH}_{\mathrm{HH}}=3.4 \mathrm{~Hz}, \mathrm{CH}\right), 1.7 \mathrm{O}\left({ }_{15} \mathrm{H}, \mathrm{s}, \mathrm{C}_{5}\left(\mathrm{CH}_{3}\right)_{5}\right), 1.57-1.54$ $(1 \mathrm{H}, \mathrm{m}, \mathrm{CH}), 0.8 \mathrm{o}\left(3 \mathrm{H}, \mathrm{d}, 3_{\mathrm{HH}}=7.1 \mathrm{~Hz}, \mathrm{CH}_{3}\right),-0.04\left(3 \mathrm{H}, \mathrm{d}, 3_{\mathrm{HH}}=\right.$ $\left.\left.6.7 \mathrm{~Hz}, \mathrm{CH}_{3}\right) .{ }^{13} \mathrm{C}^{1} \mathrm{H}\right\}$ NMR $\left(125 \mathrm{MHz}, \mathrm{MeCN}-\mathrm{d}^{3}\right): 178.8(\mathrm{C}=\mathrm{N}), 136.6$ $(\operatorname{ArC})$, $130.5(\operatorname{ArC}), 129.1(\operatorname{ArC}), 127.9(\operatorname{ArC}), 107.3(\mathrm{CpC}), 91.3$ $\left(\mathrm{C}_{5}\left(\mathrm{CH}_{3}\right)_{5}\right)$, 91.2 $(\mathrm{CpC})$, 87.1 $(\mathrm{CpC})$, 86.5 $(\mathrm{CpC}), 83.2(\mathrm{CpC}), 77.8$ $\left(C_{4} \mathrm{Ph}_{4}\right), 73.6\left(\mathrm{CH}_{2}\right), 67.5(\mathrm{CH})$, 30.0 $(\mathrm{CH})$, $19.9\left(\mathrm{CH}_{3}\right), 15.5\left(\mathrm{CH}_{3}\right)$, 9.5 $\left(\mathrm{C}_{5}\left(\mathrm{CH}_{3}\right)_{5}\right)$. High-resolution MS $\left(\mathrm{m} / \mathrm{z}, \mathrm{NSI}^{+}\right)$: found for [M- $\left(\mathrm{PF}_{6}\right.$ $+\mathrm{MeCN})]^{+}=918.2679$, calcd for $\mathrm{C}_{49} \mathrm{H}_{48} \mathrm{CoIrNO}^{+}$918.2693.
Synthesis
of
$\left(S, S_{\mathrm{p}}, S_{\mathrm{Ir}}\right)-\mathbf{9}$.
$\left(\eta^{5}-(S)-2-(4-T e r t-\right.$ butyl)oxazolinylcyclopentadienyl)-( $\eta^{4-}$

tetraphenylcyclobutadiene) cobalt $^{6 \mathrm{~b}}(0.038 \mathrm{~g}, 0.06 \mathrm{mmol})$, was cycloiridated using the general procedure with a reactime time of 7 days to yield the product as an amorphous orange solid (0.018 g, 27\%). $[\alpha]_{D^{22}}{ }^{\circ} \mathrm{C}=-337$ (c o.88, MeCN). ${ }^{1} \mathrm{H}$ NMR (50o MHz, MeCN$\left.\mathrm{d}^{3}\right): 7.51$ - $7.47(8 \mathrm{H}, \mathrm{m}, \mathrm{ArH}), 7.32$ - $7.21(12 \mathrm{H}, \mathrm{m}, \mathrm{Ar} H), 5.44(\mathrm{lH}, \mathrm{dd}$, $\left.3 J_{\mathrm{HH}}=2.3,4 J_{\mathrm{HH}}=1.0 \mathrm{~Hz}, \mathrm{Cp} H\right), 5.07\left(1 \mathrm{H}, \mathrm{dd}, 3 J_{\mathrm{HH}}=2.6,4 J_{\mathrm{HH}}=1.0\right.$ $\mathrm{Hz}, \mathrm{Cp} H), 4.73\left(1 \mathrm{H}, \mathrm{apt}, 3 J_{\mathrm{HH}}=2.5 \mathrm{~Hz}, \mathrm{Cp} H\right), 4.58\left(1 \mathrm{H}, \mathrm{dd},{ }^{2} J_{\mathrm{HH}}=\right.$ $\left.10.2,3 J_{\mathrm{HH}}=9.3 \mathrm{~Hz}, \mathrm{CHH}\right), 4.50\left(1 \mathrm{H}, \mathrm{dd},{ }^{2} J_{\mathrm{HH}}=9.3,{ }^{3} J_{\mathrm{HH}}=6.1 \mathrm{~Hz}\right.$, $\mathrm{CHH}), 3.76\left(1 \mathrm{H}, \mathrm{dd}, 33_{\mathrm{HH}}=10.2,3 J_{\mathrm{HH}}=6.1 \mathrm{~Hz}, \mathrm{CH}\right), 1.66(15 \mathrm{H}, \mathrm{s}$, $\left.\mathrm{C}_{5}\left(\mathrm{CH}_{3}\right)_{5}\right), 0.56\left({ }_{9} \mathrm{H}, \mathrm{s}, \mathrm{CH}_{3}\right) .{ }^{13} \mathrm{C}\left\{{ }^{1} \mathrm{H}\right\}$ NMR $\left(125 \mathrm{MHz}, \mathrm{MeCN}-\mathrm{d}^{3}\right)$ : 
180.6 $(C=\mathrm{N}), 136.8(\operatorname{ArC}), 130.5(\operatorname{ArC})$, $129.2(\operatorname{ArC})$, 128.o $(\operatorname{ArC})$, 107.4 ( $\mathrm{CpC})$, 91.7 $\left(\mathrm{C}_{5}\left(\mathrm{CH}_{3}\right)_{5}\right)$, 91.5 $(\mathrm{CpC})$, 87.3 $(\mathrm{CpC})$, $86.6(\mathrm{CpC})$, 83.1 $(\mathrm{CpC})$, $77.6\left(\mathrm{C}_{4} \mathrm{Ph}_{4}\right)$, $74.8\left(\mathrm{CH}_{2}\right)$, 70.6 $(\mathrm{CH})$, 35.0 $\left(\mathrm{C}\left(\mathrm{CH}_{3}\right)_{3}\right)$, $25.9\left(\mathrm{CH}_{3}\right), 9.8\left(\mathrm{C}_{5}\left(\mathrm{CH}_{3}\right)_{5}\right)$. High-resolution MS $\left(\mathrm{m} / \mathrm{z}, \mathrm{NSI}^{+}\right)$: found for $\left[\mathrm{M}-\left(\mathrm{PF}_{6}+\mathrm{MeCN}\right)\right]^{+}=932.2851$, calcd for $\mathrm{C}_{50} \mathrm{H}_{50} \mathrm{CoIrNO}^{+}$ 932.2852.

Synthesis of $\quad\left(S, S_{\mathbf{p}}, S_{\text {Ir }}\right)$-11. $\quad(S)$-2-Ferrocenyl-4-tertbutyloxazoline ${ }^{21}(0.020 \mathrm{~g}, 0.06 \mathrm{mmol}$ ) was cycloiridated using the general procedure with an overnight reaction time to yield the product as an amorphous air sensitive orange solid (o.023 g, 45\%). $[\alpha]_{\mathrm{D}^{21}}^{{ }^{\circ} \mathrm{C}}=-776$ (c o.3, MeCN). IR (film): 2960, 2920, 2877, 1594 $(\mathrm{C}=\mathrm{N}), 842$, 560. ${ }^{1} \mathrm{H}$ NMR $(500 \mathrm{MHz}, \mathrm{MeCN}-\mathrm{d} 3): 4.83\left(\mathrm{iH}, \mathrm{dd},{ }^{2} J_{\mathrm{HH}}\right.$ $\left.=9.4,{ }^{3} \mathrm{JH}_{\mathrm{HH}}=5.1 \mathrm{~Hz}, \mathrm{CHH}\right), 4.65\left(1 \mathrm{H}, \mathrm{apt},{ }^{2} J_{\mathrm{HH}}=9.7 \mathrm{~Hz}, \mathrm{CHH}\right), 4.64$ $\left(1 \mathrm{H}, \mathrm{dd},{ }^{3} J_{\mathrm{HH}}=2.2,{ }^{4} J_{\mathrm{HH}}=0.7 \mathrm{~Hz}, \mathrm{Cp} H\right), 4.58\left(1 \mathrm{H}, \mathrm{dd},{ }^{3} J_{\mathrm{HH}}=2.3,{ }^{4} J_{\mathrm{HH}}\right.$ $=0.7 \mathrm{~Hz}, \mathrm{Cp} H), 4.55\left(1 \mathrm{H}\right.$, apt, $\left.{ }^{3} J_{\mathrm{HH}}=2.3 \mathrm{~Hz}, \mathrm{Cp} H\right), 4.16(5 \mathrm{H}, \mathrm{s}$, $\mathrm{CpH}), 3.85\left(1 \mathrm{H}, \mathrm{dd}, 33_{\mathrm{HH}}=10.0,33_{\mathrm{HH}}=5.1 \mathrm{~Hz}, \mathrm{CH}\right), 1.59(15 \mathrm{H}, \mathrm{s}$, $\left.\mathrm{C}_{5}\left(\mathrm{CH}_{3}\right)_{5}\right)$, 1.01 $\left.\left(9 \mathrm{H}, \mathrm{s}, \mathrm{CH}_{3}\right) .{ }^{13} \mathrm{C}^{1}{ }^{1} \mathrm{H}\right\}$ NMR $\left(125 \mathrm{MHz}, \mathrm{MeCN}-\mathrm{d}^{3}\right)$ : 185.1 $(\mathrm{C}=\mathrm{N})$, $96.4(\mathrm{CpC})$, $91.2\left(\mathrm{C}_{5}\left(\mathrm{CH}_{3}\right)_{5}\right)$, 75.0 $\left(\mathrm{CH}_{2}\right)$, $74.9(\mathrm{CpC})$, 74.0 (CpC), 71.7 (CpC), 70.4 (CH), 70.0 ( $\mathrm{CpC})$, 65.5 ( $\mathrm{CpC})$, 35.1 $\left(\mathrm{C}\left(\mathrm{CH}_{3}\right)_{3}\right)$, 26.0 $\left(\mathrm{CH}_{3}\right)$, 9.4 $\left(\mathrm{C}_{5}\left(\mathrm{CH}_{3}\right)_{5}\right)$. High-resolution MS $(\mathrm{m} / \mathrm{z}$, $\left.\mathrm{NSI}^{+}\right)$: found for $\left[\mathrm{M}-\mathrm{PF}_{6}-\mathrm{MeCN}\right]^{+}=638.1672$, calcd for $\mathrm{C}_{27} \mathrm{H}_{35} \mathrm{FeIrNO}^{+} 638.1693$.

Synthesis of $\left(S, S_{\mathrm{p}}, S_{\mathrm{Ir}}\right)-2$ (d.r. 48 : 1). (S)-2-Ferrocenyl-4-(1methylethyl)oxazoline ${ }^{21}$ (0.019 g, $0.06 \mathrm{mmol}$ ) was cycloiridated using the general procedure with an overnight reaction time to yield the product as an amorphous air sensitive orange solid (0.02 g, $38 \%)$. Characterization data as previously reported. 5

Transformation of iridacycles $\left(S, S_{\mathrm{p}}, S_{\mathrm{Ir}}\right)-7 \&\left(S, R_{\mathrm{p}}, R_{\mathrm{Ir}}\right)-8$ (d.r. $1.2: 1)$ into $(S)$-12 and $(Z)$-13. Iridacycles $\left(S, S_{\mathrm{p}}, S_{\mathrm{Ir}}\right)-7$ and $\left(S, R_{\mathrm{p}}, R_{\mathrm{Ir}}\right)-$ 8 (d.r. $1.2: 1$ ) (o.031 g, $0.028 \mathrm{mmol}$ ) were dissolved in deuterated acetonitrile (not distilled or degassed) and stirred in a Schlenk tube at $45{ }^{\circ} \mathrm{C}$ for 8 days. A proton NMR spectrum was recorded each day after allowing the reaction to cool to room temperature. After 8 days the reaction mixture showed a mixture of compounds $(S)-11$ and $(Z)-\mathbf{1 2}$. Characterization data for $(S)-12^{15}$ and $(Z)-13^{22}$ as previously reported. See supporting information for a comparison of the NMR spectra over a period of 8 days and for a representation of $(Z)$-13 as determined by X-ray crystallography.

Transformation of a mixture of $\left(S, S_{\mathrm{p}}, S_{\mathrm{Ir}}\right)-9$ and $\left(S, S_{\mathrm{p}}, S_{\mathrm{Ir}}\right)-11$ into $(S)$-14. A mixture of $\left(S, S_{\mathrm{p}}, S_{\mathrm{Ir}}\right)-\mathbf{9}(0.031 \mathrm{~g}, 0.028 \mathrm{mmol})$ and $\left(S, S_{\mathrm{p}}, S_{\text {Ir }}\right)-11$ (o.015 g, $\left.0.018 \mathrm{mmol}\right)$ was dissolved in acetonitrile (not distilled or degassed) and stirred in a Schlenk tube at $45^{\circ} \mathrm{C}$. After 8 days the solvent was removed in vacuo. Analysis by ${ }^{1} \mathrm{H}$ NMR spectroscopy revealed the absence of $\left(S, S_{\mathrm{p}}, S_{\mathrm{II}}\right)$-11 and a $1.1: 1$ ratio of $(S)-\mathbf{1 4}$ and $\left(S, S_{\mathrm{p}}, S_{\mathrm{Ir}}\right)-\mathbf{9}$. The mixture was purified by column chromatography on neutral alumina using acetonitrile as the eluent resulting isolation of a yellow solid (0.003 g, $11 \%$ ) (low yield due to the difficulty in separating $\left(S, S_{\mathrm{p}}, S_{\mathrm{Ir}}\right)-\mathbf{9}$ and $(S)-\mathbf{1 4}$ on a column).

Mp: $144-146^{\circ} \mathrm{C} .[\alpha]_{D^{23}}{ }^{\circ} \mathrm{C}=-29.4(c 0.34, \mathrm{MeCN})$. IR (film): 2954, 2925, 2871, 2856, $1662(\mathrm{C}=\mathrm{N}), 840 .{ }^{1} \mathrm{H}$ NMR (500 MHz, MeCN-d 3 ): $5.89\left(1 \mathrm{H}, \mathrm{dd}, 3 J_{\mathrm{HH}}=3.6,{ }^{4} J_{\mathrm{HH}}=1.4 \mathrm{~Hz}, \mathrm{Cp} H\right), 5.85\left(1 \mathrm{H}, \mathrm{dd},{ }^{3} J_{\mathrm{HH}}=3.3\right.$, $\left.{ }^{4} J_{\mathrm{HH}}=1.7 \mathrm{~Hz}, \mathrm{Cp} H\right), 5.64\left(2 \mathrm{H}, \mathrm{apt},{ }^{3} J_{\mathrm{HH}}=1.7 \mathrm{~Hz}, \mathrm{CpH}\right), 4.38(1 \mathrm{H}$, $\left.\mathrm{dd},{ }^{2} J_{\mathrm{HH}}=10.2,{ }^{3} J_{\mathrm{HH}}=8.9 \mathrm{~Hz}, \mathrm{CHH}\right), 4.19\left(\mathrm{lH}, \mathrm{apt},{ }^{2} J_{\mathrm{HH}}=9.0 \mathrm{~Hz}\right.$, $\mathrm{CHH}), 4.04\left(1 \mathrm{H}, \mathrm{dd}, 3 J_{\mathrm{HH}}=10.2,33_{\mathrm{HH}}=9.1 \mathrm{~Hz}, \mathrm{CH}\right), 2.12(15 \mathrm{H}, \mathrm{s}$, $\left.\left.\mathrm{C}_{5}\left(\mathrm{CH}_{3}\right)_{5}\right), 0.91\left(9 \mathrm{H}, \mathrm{s}, \mathrm{CH}_{3}\right),{ }^{13} \mathrm{C}^{1}{ }^{1} \mathrm{H}\right\}$ NMR $\left(125 \mathrm{MHz}, \mathrm{MeCN}-\mathrm{d}^{3}\right)$ : $157.7(C=\mathrm{N})$, $99.6\left(\mathrm{C}_{5}\left(\mathrm{CH}_{3}\right)_{5}\right), 86.1(\mathrm{CpC}), 83.4(\mathrm{CpC}), 81.4(\mathrm{CpC})$, 81.4 (CpC), 77.4 (CH), 70.3 $\left(\mathrm{CH}_{2}\right), 34.2\left(\mathrm{C}\left(\mathrm{CH}_{3}\right)_{3}\right), 26.1\left(\mathrm{CH}_{3}\right), 10.2$ $\left(\mathrm{C}_{5}\left(\mathrm{CH}_{3}\right)_{5}\right)$. High-resolution MS $\left(\mathrm{m} / \mathrm{z}, \mathrm{NSI}^{+}\right)$: found for $\left[\mathrm{M}-\mathrm{PF}_{6}\right]^{+}=$ 518.2017, calcd for $\mathrm{C}_{22} \mathrm{H}_{31} \mathrm{IrNO}^{+}$518.2030.

Synthesis of $\left(S, S_{\mathrm{p}}, R_{\mathrm{Ir}}\right)-15 \&\left(S, R_{\mathrm{p}}, S_{\mathrm{Ir}}\right)-16$. General Method 1. Iridacycles $\left(S, S_{\mathrm{p}}, S_{\mathrm{Ir}}\right)-7 \&\left(S, R_{\mathrm{p}}, R_{\mathrm{Ir}}\right)-8$ (d.r. $\left.1.7: 1\right) \quad(0.033 \mathrm{~g}, 0.03$ $\mathrm{mmol}$ ) was added to a flame dried round bottomed flask under an inert atmosphere and dissolved in dry dichloromethane $(5 \mathrm{~mL})$.
To this, a solution of tetra- $n$-butylammonium chloride ( $0.008 \mathrm{~g}$, $0.03 \mathrm{mmol})$ in dry dichloromethane $(1 \mathrm{~mL})$ was added causing an immediate colour change from brown green to bright orange. The reaction was allowed to stir at room temperature for $1 \mathrm{~h}$ before removal of the solvent in vacuo. Excess tetra- $n$-butylammonium chloride was removed by re-dissolving the orange residue in hexane/dichloromethane and washing with brine ( 4 × $50 \mathrm{~mL})$. The organic layer was dried by filtering through a glass wool pad loaded with magnesium sulfate followed by removal of the solvent in vacuo to give a tacky orange solid (o.02 g, $78 \%$ ).

Method 2. To a round bottomed flask containing iridacycles $\left(S, S_{\mathrm{p}}, S_{\mathrm{Ir}}\right)-7 \&\left(S, R_{\mathrm{p}}, R_{\mathrm{Ir}}\right)-8$ (d.r. $\left.1.2: 1\right)(0.027 \mathrm{~g}, 0.03 \mathrm{mmol})$ and potassium chloride $(0.028 \mathrm{~g}, 0.38 \mathrm{mmol})$ was added methanol (3 $\mathrm{mL}$ ) to give a brown/orange solution. The reaction was allowed to stir at room temperature for $\mathrm{i}$ h before filtering through neutral alumina using methanol as the eluent. The solvent was removed in vacuo to give the crude product ( $0.02 \mathrm{~g}, 86 \%$ ). This was redissolved in ethyl acetate and transferred to an NMR tube whereby hexane was carefully layered on top and the solvents allowed to slowly diffuse and evaporate to give crystals suitable for X-ray analysis.

Mp: $180-182{ }^{\circ} \mathrm{C}$. High-resolution MS $\left(\mathrm{m} / \mathrm{z}, \mathrm{APCI}^{+}\right)$: found for $[\mathrm{M}+\mathrm{H}]^{+}=954.2457$, calcd for $\mathrm{C}_{49} \mathrm{H}_{48} \mathrm{CoIrNOCl}+\mathrm{H}^{+}$954.2453. Note: The proton NMR spectrum was very broad and proved to be unassignable (see Supporting Information).

Transformation of $\left(S, S_{\mathrm{p}}, R_{\mathrm{Ir}}\right)-15 \&\left(S, R_{\mathrm{p}}, S_{\mathrm{Ir}}\right)-16$ into $\left(S, S_{\mathrm{p}}, S_{\mathrm{Ir}}\right)-7$ \& $\left(\boldsymbol{S}, \boldsymbol{R}_{\mathrm{p}}, \boldsymbol{R}_{\mathrm{Ir}}\right)-\mathbf{8}$. To a flame dried Schlenk tube under an inert atmosphere were added $\left(S, S_{\mathrm{p}}, R_{\mathrm{Ir}}\right)-\mathbf{1 5} \&\left(S, R_{\mathrm{p}}, S_{\mathrm{Ir}}\right)$-16 obtained from Method $1 \quad(0.021 \mathrm{~g}, \quad 0.02 \mathrm{mmol})$ and potassium hexafluorophosphate (0.016 g, $0.09 \mathrm{mmol})$. After dissolution in acetonitrile the reaction mixture was stirred for $2 \mathrm{~h}$ at room temperature. The reaction mixture was washed with hexane until the hexane layer became colourless. The acetonitrile layer was reduced in vacuo. Purification was achieved by filtering through a short pad of neutral alumina, using acetonitrile as the eluent, and collecting the first bright orange fractions. Removal of the solvent in vacuo yielded the desired product as an amorphous orange solid (o.017 g, 69\%, d.r. $1.7: 1$ ).

Synthesis of $\left(\boldsymbol{S}, \boldsymbol{S}_{\mathrm{p}}, \boldsymbol{R}_{\mathrm{Ir}}\right)-19 \&\left(\boldsymbol{S}, \boldsymbol{R}_{\mathrm{p}}, \boldsymbol{S}_{\mathrm{Ir}}\right)$-2o. Iridacycles $\left(S, S_{\mathrm{p}}, S_{\mathrm{Ir}}\right)-\mathbf{7}$ \& $\left(S, R_{\mathrm{p}}, R_{\mathrm{Ir}}\right)-8(2: 1)(0.022 \mathrm{~g}, 0.02 \mathrm{mmol})$ was added to a flame dried round bottomed flask under an inert atmosphere and dissolved in dry dichloromethane $(2 \mathrm{~mL})$. To this, a solution of triphenylphosphine $(0.053 \mathrm{~g}, 0.20 \mathrm{mmol})$ in dichloromethane (1 $\mathrm{mL}$ ) was added causing an immediate colour change from brown green to bright orange. The reaction was allowed to stir at room temperature for $\mathrm{i} \mathrm{h}$ before concentrating under reduced pressure. Addition of hexane caused a precipitate to form which was collected via filtration and washed with copious amounts of hexane to remove excess triphenylphosphine. Drying in air yielded a red powder (o.03 g, 85\%, d.r. $2: 1$ ).

NMR data for major diastereoisomer: Mp: $182-183^{\circ} \mathrm{C}$. $[\alpha]_{\mathrm{D}^{23} \cdot 9^{\circ} \mathrm{C}=}=$ $-504\left(\text { c 0.1, } \mathrm{CHCl}_{3}\right)^{*}$. IR (film): 3058, 2963, 2923, 2868, $1586(\mathrm{C}=\mathrm{N})$, 838. ${ }^{1} \mathrm{H}$ NMR (5oo MHz, $\left.\mathrm{CDCl}_{3}\right): 7.46-7.08\left({ }_{15} \mathrm{H}, \mathrm{m}, \mathrm{PPh}_{3}\right), 7.40-$ $7.36(8 \mathrm{H}, \mathrm{m}, \mathrm{Ar} H), 7.29$ - $7.27(4 \mathrm{H}, \mathrm{m}, \mathrm{Ar} H), 7.22$ - $7.18(8 \mathrm{H}, \mathrm{Ar} H)$, $5.32(\mathrm{lH}$, brs, $\mathrm{CpH}), 4.54\left(\mathrm{lH}, \mathrm{dd},{ }^{2} J_{\mathrm{HH}}=9.3,{ }^{3} J_{\mathrm{HH}}=5.0 \mathrm{~Hz}, \mathrm{CHH}\right)$, $4.37\left(\mathrm{HH}\right.$, apd, $\left.{ }^{2} J_{\mathrm{HH}}=9.7 \mathrm{~Hz}, \mathrm{CH}\right), 4.33(\mathrm{iH}$, brs, $\mathrm{Cp} H), 4.29(\mathrm{iH}$, brs, $\mathrm{CpH}), 3.76-3.70(\mathrm{l} H, \mathrm{~m}, \mathrm{CH}), 1.97-1.90(\mathrm{lH}, \mathrm{m}, \mathrm{CH}), 1.31(15 \mathrm{H}$, d, $\left.{ }^{4} J_{\mathrm{HP}}=1.5 \mathrm{~Hz}, \mathrm{C}_{5}\left(\mathrm{CH}_{3}\right)_{5}\right), 0.96\left({ }_{3} \mathrm{H}, \mathrm{d},{ }^{3} J_{\mathrm{HH}}=7.0 \mathrm{~Hz}, \mathrm{CH}_{3}\right), 0.43$ $\left(3 \mathrm{H}, \mathrm{d},{ }^{3} J_{\mathrm{HH}}=6.7 \mathrm{~Hz}, \mathrm{CH}_{3}\right) \cdot{ }^{13} \mathrm{C}\left\{{ }^{1} \mathrm{H}\right\}$ NMR $\left(125 \mathrm{MHz}, \mathrm{CDCl}_{3}\right): 179 \cdot 3$ $(C=\mathrm{N}), 135.7(\operatorname{ArC})$, 134.0 $(\operatorname{ArC}), 132.2\left(\mathrm{~d},{ }^{1} J_{\mathrm{CP}}=10.0 \mathrm{~Hz}, \operatorname{ArC}\right), 129.5$ $\left(\mathrm{d},{ }^{2} J_{\mathrm{CP}}=18.5 \mathrm{~Hz}, \operatorname{ArC}\right), 129.1(\operatorname{ArC}), 128.5(\operatorname{ArC}), 128.3(\operatorname{ArC}), 127.2$ $(\mathrm{ArC}), 122.4\left(\mathrm{~d},{ }^{3} J_{\mathrm{CP}}=9.8 \mathrm{~Hz}, \mathrm{CpC}\right), 95.8\left(\mathrm{~d},{ }^{2} J_{\mathrm{CP}}=2.2 \mathrm{~Hz}, \mathrm{C}_{5}\left(\mathrm{CH}_{3}\right)_{5}\right)$, 90.8 ( $\mathrm{CpC})$, 90.5 ( $\mathrm{CpC})$, 90.4 ( $\mathrm{CpC})$, 77.5 ( $\mathrm{CpC})$, $75.9\left(C_{4} \mathrm{Ph}_{4}\right), 71.8$ $\left(\mathrm{CH}_{2}\right), 69.4(\mathrm{CH}), 29.3(\mathrm{CH}), 19.1\left(\mathrm{CH}_{3}\right), 15.4\left(\mathrm{CH}_{3}\right), 9.9\left(\mathrm{C}_{5}\left(\mathrm{CH}_{3}\right)_{5}\right)$, 
${ }^{31} \mathrm{P}\left\{{ }^{1} \mathrm{H}\right\}$ NMR (202 MHz, $\left.\mathrm{CDCl}_{3}\right): 7.13$ (s, $1 \mathrm{P}, \mathrm{PPh}_{3}$ ), -144.33 (hept, $1 \mathrm{P}$, $\left.J_{\mathrm{PF}}=712.4 \mathrm{~Hz}, \mathrm{PF}_{6}\right)$. High-resolution $\mathrm{MS}\left(\mathrm{m} / \mathrm{z}, \mathrm{NSI}^{+}\right)$: found for $\left[\mathrm{M}-\mathrm{PF}_{6}\right]^{+}=1180.3597$, calcd for $\mathrm{C}_{67} \mathrm{H}_{63} \mathrm{CoIrNOP}^{+}{ }_{1180.3608 \text {. Note: * }}$ $=$ ratio of 7.4:1 (obtained from a different reaction).

Crystal structure analysis of $\left(S, S_{\mathrm{P}}, \boldsymbol{R}_{\mathrm{Ir}}\right)-\mathbf{1 5}$. Crystal data: $\mathrm{C}_{49} \mathrm{H}_{48} \mathrm{ClCoIrNO}, \mathrm{M}=953.46$. Monoclinic, space group $\mathrm{P}_{2}$ (no. 4), $\mathrm{a}=10.0619(2), \mathrm{b}=12.0816(3), \mathrm{c}=17.0228(4) \AA, \beta=105.350(2)^{\circ}$, $\mathrm{V}=1995.54(8) \AA^{3} . \mathrm{Z}=2, \mathrm{Dc}=1.587 \mathrm{~g} \mathrm{~cm}^{-3}, \mathrm{~F}($ ooo $)=956, \mathrm{~T}=14 \mathrm{O}(1)$ $\mathrm{K}, \mu(\mathrm{Mo}-\mathrm{K} \alpha)=38.5 \mathrm{~cm}^{-1}, \lambda(\mathrm{Mo}-\mathrm{K} \alpha)=0.71069 \AA$.

Crystals are pink-orange rectangular prisms. One, ca $0.40 \mathrm{x} 0.11 \mathrm{x}$ $0.045 \mathrm{~mm}$, was mounted in oil on a glass fibre and fixed in the cold nitrogen stream on an Oxford Diffraction Xcalibur3/Sapphire3-CCD diffractometer, equipped with Mo-K $\alpha$ radiation and graphite monochromator. Intensity data were measured by thin-slice $\omega$ - and $\phi$-scans. Total no. of reflections recorded, to $\theta_{\max }=30^{\circ}$, was 38619 of which 11599 were unique (Rint $=0.036$ ); 10981 were 'observed' with $\mathrm{I}>2 \sigma_{\mathrm{I}}$. Data were processed using the CrysAlisPro-CCD and -RED programs. ${ }^{23}$ The structure was determined by the direct methods routines in the SHELXS program $^{24}$ and refined by full-matrix least-squares methods, on $\mathrm{F}^{2} \mathrm{~s}$, in SHELXL.25 The non-hydrogen atoms were refined with anisotropic thermal parameters. Hydrogen atoms were included in idealised positions and their Uiso values were set to ride on the Ueq values of the parent carbon atoms. At the conclusion of the refinement, $w R_{2}=0.062$ and $R_{1}=0.030$ (28) for all 11599 reflections weighted $\mathrm{w}=\left[\sigma^{2}\left(\mathrm{~F}_{\mathrm{o}}^{2}\right)+(0.0346 \mathrm{P})^{2}+0.291 \mathrm{P}\right]^{-1}$ with $\mathrm{P}=\left(\mathrm{F}_{\mathrm{o}}^{2}+\right.$ $\left.2 \mathrm{~F}_{\mathrm{c}}^{2}\right) / 3$; for the 'observed' data only, $\mathrm{R}_{1}=0.027$. In the final difference map, the highest peaks (to $c a 1.5 \mathrm{e}^{-3}$ ) were close to the iridium atom. Previoulsy determined cattering factors for neutral atoms were employed. ${ }^{26}$ Computer programs used in this analysis have been noted above, and were run through WinGX ${ }^{27}$ on a Dell Optiplex 755 PC at the University of East Anglia.

\section{ASSOCIATED CONTENT}

\section{Supporting Information}

Copies of the ${ }^{1} \mathrm{H},{ }^{13} \mathrm{C},{ }^{31} \mathrm{P}$ NMR and $\mathrm{CD}$ spectra and X-ray crystallography details (PDF file). CCDC 1855096, 1855097 and 1855133 contain supplementary X-ray crystallographic data for $\left(S, S_{\mathrm{P}}, R_{\mathrm{Ir}}\right)-\mathbf{1 5},\left(S, R_{\mathrm{p}}, S_{\mathrm{Ir}}\right)-16$ and $(Z)-13$, respectively. This data can be obtained free of charge via http://www.ccdc. cam.ac.uk/conts/retrieving.html, or from the Cambridge Crystallographic Data Centre, Union Road, Cambridge, CB2 1EZ; fax (+44) 1223-336-033 or e-mail: deposit@ccdc.cam.ac. uk. The Supporting Information is available free of charge on the ACS Publications website.

\section{AUTHOR INFORMATION}

\section{Corresponding Author}

*Email: Chris.Richards@uea.ac.uk

Notes

The authors declare no competing financial interest.

\section{ACKNOWLEDGMENT}

The AI-Chem Channel and the the EPSRC (EP/No19393/1) (R.A.A.) are thanked for financial support. We also thank the EPSRC National Mass Spectrometry Centre (University of Wales, Swansea), Myles Cheesman (UEA) for assistance with and use of the UEA circular dichroism facility, and Muhammad Ismail for preliminary experiments. V.S.O. and
C.C.P. wish to thank the Research Computing Service at the University of East Anglia for access to the High Performance Computing Cluster.

\section{REFERENCES}

(1) Albrecht, M. Cyclometalation Using d-Block Transition Metals: Fundamental Aspects and Recent Trends. Chem. Rev. 2010, 110, 576-623.

(2) (a) Dupont, J.; Consorti, C. S.; Spencer, J. The Potential of Palladacycles: More Than Just Precatalysts. Chem. Rev. 2005, 105, 2527-2572. (b) Djukic, J.-P.; Sortais, J.-B.; Barloy, L.; Pfeffer, M. Cycloruthenated Compounds - Synthesis and Applications. Eur. J. Inorg. Chem. 2009, 7, 817-853. (c) Michon, C.; MacIntyre, K.; Corre, Y.; Agbossou-Niedercorn, F. Pentamethylcyclopentadienyl Iridium(III) Metallacycles Applied to Homogeneous Catalysis for Fine Chemical Synthesis. Chem. Cat. Chem. 2o16, 8, 1755-1762. (d) Wang, C.; Xiao, J. Iridacycles for Hydrogenation and Dehydrogenation Reactions. Chem. Commun. 2017, 53, 3399-3411. (e) Hazari, N.; Melvin, P. R.; Beromi, M. M. Well-Defined Nickel and Palladium Precatalysts for Cross-Coupling. Nat. Rev. Chem. 2017, 1, 0025.

(3) (a) Djukic, J.-P.; Hijazi, A.; Flack, H. D.; Bernardinelli, G. NonRacemic (Scalemic) Planar-chiral Five-membered Metallacycles: Routes, Means, and Pitfalls in their Synthesis and Characterization. Chem. Soc. Rev. 2008, 37, 406-425. (b) C. J. Richards, in Chiral Ferrocenes in Asymmetric Catalsis: Synthesis and Applications (Eds.: L.-X. Dai, X.-L. Hou) Wiley-VCH, Weinheim, 2010, pp. 337-368.(c) Nomura, H.; Richards, C. J. Allylic Imidate Rearrangements Catalyzed by Planar Chiral Palladacycles. Chem. Asian J. 2010, 5, 1726-1740. (d) Dunina, V. V.; Gorunova, O. N.; Zykov, P. A.; Kochetkov, K. A. Cyclopalladated Complexes in Enantioselective Catalysis. Russ. Chem. Rev. 2011, $80,51-74$.

(4) Xia, J.-B.; You, S.-L. Carbon-Carbon Bond Formation through Double sp ${ }^{2} \mathrm{C}-\mathrm{H}$ Activations: Synthesis of Ferrocenyl Oxazoline Derivatives Organometallics. 2007, 26, 4869-4871.

(5) Arthurs, R. A.; Ismail, M.; Prior, C. C.; Oganesyan, V. S.; Horton, P. N.; Coles, S. J.; Richards, C. J. Enantiopure FerroceneBased Planar-Chiral Iridacycles: Stereospecific Control of IridiumCentred Chirality. Chem. Eur. J. 2016, 22, 3065-3072.

(6) (a) Stevens, A. M.; Richards, C. J. Synthesis and Highly Diastereoselective Palladation of $\left(\eta^{5}-(S)-2-\left(4^{-}\right.\right.$ Methylethyl)oxazolinylcyclopentadienyl) $\left(\eta^{4-}\right.$

tetraphenylcyclobutadiene)cobalt. Organometallics 1999, 18 , 1346-1348. (b) Prasad, R. S.; Anderson, C. E.; Richards, C. J.; Overman, L. E. Synthesis of tert-Leucine-Derived Cobalt Oxazoline Palladacycles. Reversal of Palladation Diastereoselectivity and Application to the Asymmetric Rearrangement of $\mathrm{N}$-Aryl Trifluoroacetimidates. Organometallics 2005, 24, 77-81. (c) Yeamine, M. R.; Richards, C. J. An Investigation into the Diastereoselective Palladation of Oxazoline Appended Cobalt Metallocenes. Tetrahedron: Asymmetry 2007, 18, 2613-2616. (7) Cassar, D. J.; Roghzai, H.; Villemin, D.; Horton, P. N.; Coles, S. J.; Richards, C. J. Chirality Control in Planar Chiral Cobalt Oxazoline Palladacycles. Organometallics 2015, 34, 2953-2961.

(8) Cannon, J. S.; Overman, L. E. Palladium(II)-Catalyzed Enantioselective Reactions Using COP Catalysts. Acc. Chem. Res. 2016, 49, 2220-2231.

(9) Günay, M. E.; Hughes, D. L.; Richards, C. J. Diastereoselective Synthesis of Planar Chiral Cobalt Metallocene Based Oxazoline Platinacycles. Organometallics 2011, 30, 3901-3904.

(10) Selected examples: (a) Hull, J. F.; Balcells, D.; Blakemore, J. D.; Incarvito, C. D.; Eisenstein, O.; Brudvig, G. W.; Crabtree, R. H. Highly Active and Robust $\mathrm{CP}^{*}$ Iridium Complexes for Catalytic 
Water Oxidation. J. Am. Chem. Soc. 2009, 131, 8730-8731. (b) Kashiwame, Y.; Kuwata, S.; Ikariya, T. Metal-Pyrazole Bifunction in Half-Sandwich C-N Chelate Iridium Complexes: PyrazolePyrazolato Interconversion and Application to Catalytic Intramolecular Hydroamination of Aminoalkene. Chem. Eur. J. 2010, 16, 766-770. (c) Wang, C.; Pettman, A.; Bacsa, J.; Xiao, J. A Versatile Catalyst for Reductive Amination by Transfer Hydrogenation. Angew. Chem. Int. Ed. 2010, 49, 7548-7552. (d) Watanabe, M.; Kashiwame, Y.; Kuwata, S.; Ikariya, T. Synthesis, Structures, and Transfer Hydrogenation Catalysis of Bifunctional Iridium Complexes Bearing a C-N Chelate Oxime Ligand. Eur. J. Inorg. Chem. 2012, 504-511. (e) Wu, J.; Talwar, D.; Johnston, S.; Yan, M.; Xiao, J. Acceptorless Dehydrogenation of Nitrogen Heterocycles with a Versatile Iridium Catalyst. Angew. Chem. Int. Ed. 2013, 52, 6983-6987. (f) Talwar, D.; Salguero, N. P.; Robertson, C. M.; Xiao, J. Primary Amines by Transfer Hydrogenative Reductive Amination of Ketones by Using Cyclometalated Ir ${ }^{\mathrm{III}}$ Catalysts. Chem. Eur. J. 2014, 20, 245-252. (g) Corre, Y.; Iali, W.; Hamdaoui, M.; Trivelli, X.; Djukic, J.-P.; Agbossou-Niedercorn, F.; Michon, C. Efficient Hydrosilylation of Imines using Catalysts based on Iridium(III) Metallacycles. Catal. Sci. Technol. 2015, 5, 1452-1458. (h) Sato, Y.; Kayaki, Y.; Ikariya, T. Cationic Iridium and Rhodium Complexes with C-N Chelating Primary Benzylic Amine Ligands as Potent Catalysts for Hydrogenation of Unsaturated Carbon-Nitrogen Bonds. Organometallics 2016, 35, 1257-1264. (i) Corre, Y. Werlé, C.; Brelot-Karmazin, L.; Djukic, J.-P.; AgbossouNiedercorn, F.; Michon, C. Regioselective Hydrosilylation of Terminal Alkynes using Pentamethylcyclopentadienyl Iridium(III) Metallacycle Catalysts. J. Mol. Catal. A-Chem. 2016, 423, 256-263. (j) Corre, Y.; Trivelli, X.; Capet, F.; Djukic, J.-P.; Agbossou-Niedercorn, F.; Michon, C. Efficient and Selective Hydrosilylation of Secondary and Tertiary Amides Catalyzed by an Iridium(III) Metallacycle: Development and Mechanistic Investigation. ChemCatChem 2017, 9, 2009-2017. (k) Corre, Y.; Rysak, V.; Trivelli, X.; Agbossou-Niedercorn, F.; Michon, C. A Versatile Iridium(III) Metallacycle Catalyst for the Effective Hydrosilylation of Carbonyl and Carboxylic Acid Derivatives. Eur. J. Org. Chem. 2017, 4820-4826. (l) Hamdaoui, M.; Desrousseaux, C.; Habbita, H.; Djukic, J.-P. Iridacycles as Catalysts for the Autotandem Conversion of Nitriles into Amines by Hydrosilylation: Experimental Investigation and Scope. Organometallics 2017, 36, 4864-4882.

(11) (a) Arita, S.; Koike, T.; Kayaki, Y.; Ikariya, T. Synthesis and Reactivities of $\mathrm{Cp}^{*}$ Ir Amide and Hydride Complexes Bearing C-N Chelate Ligands. Organometallics 20o8, 27, 2795-2802. (b) Arita, S.; Koike, T.; Kayaki, Y.; Ikariya, T. Aerobic Oxidative Kinetic Resolution of Racemic Secondary Alcohols with Chiral Bifunctional Amido Complexes. Angew. Chem. Int. Ed. 20o8, 47, 2447-2449. (c) Jerphagnon, T.; Haak, R.; Berthiol, F.; Gayet, A. J. A.; Ritleng, V.; Holuigue, A.; Pannetier, N.; Pfeffer, M.; Voelklin, A.; Lefort, L.; Verzijl, G.; Tarabiono, C.; Janssen, D. B.; Minnaard, A. J.; Feringa, B. L.; de Vries, J. G. Ruthenacycles and Iridacycles as Catalysts for Asymmetric Transfer Hydrogenation and Racemisation. Top. Catal. 2010, 53, 1002-1008. (d) Pannetier, N.; Sortais, J.-B.; Issenhuth, J.-T.; Barloy, L.; Sirlin, C.; Holuigue, A.; Lefort, L.; Panella, L.; de Vries, J. G.; Pfeffer, M. Cyclometalated Complexes of Ruthenium, Rhodium and Iridium as Catalysts for Transfer Hydrogenation of Ketones and Imines. Adv. Synth. Catal. 2011, 353, 2844-2852. (e) Féghali, E.; Barloy, L.; Issenhuth, J.-T.; Karmazin-Brelot, L.; Bailly, C.; Pfeffer, M. Cyclometalation of $(2 R, 5 R)-2,5$-Diphenylpyrrolidine and 2-Phenyl-2-imidazoline Ligands with Half-Sandwich Iridium(III) and Rhodium(III) Complexes. Organometallics, 2013, 32, 6186-6194. (f) Chen, H. J.; Teo, R. H. X.; Li, Y.; Pullarkat, S. A.; Leung, P.-H. Stereogenic Lock in 1-Naphthylethanamine Complexes for Catalyst and Auxiliary Design: Structural and Reactivity Analysis for Cycloiridated Pseudotetrahedral Complexes. Organometallics 2018, 37, 99-106. (12) In contrast cycloplatination of $(S)$-3 results predominantly in the alternative $\left(S, R_{\mathrm{p}}\right)$-platinacycle from a reaction carried out for 3 days in refluxing xylenes. See reference 9.

(13) (a) Sammakia, T.; Latham, H. A. Ligand Effects on the Stereochemistry of the Metalation of Chiral Ferrocenyloxazolines. J. Org. Chem. 1995, 6o, 6002-6oo3. (b) Richards, C. J.; Damalidis, T.; Hibbs, D. E.; Hursthouse, M. B. Synthesis of 2-[2(Diphenylphosphino)ferrocenyl]oxazoline Ligands. Synlett 1995, 74-76. (c) Nishibayashi, Y.; Uemura, S. Asymmetric Synthesis and Highly Diastereoselective ortho-Lithiation of Oxazolinylferrocenes. Synlett 1995, 79-81.

(14) The CD spectra of related palladacycles and platinacycles display a pronounced -ve and +ve band at $\sim 340 \mathrm{~nm}$ for $S_{\mathrm{p}}$ and $R_{\mathrm{p}}$ configurations respectively. See references 7 and 9 .

(15) Arthurs, R. A.; Horton, P. N.; Coles, S. J.; Richards, C. J. Metallocene to Metallocene Conversion. Synthesis of an Oxazoline-Substituted Pentamethyliridocenium Cation from a Ferrocenyloxazoline. Chem. Commun. 2016, 52, 7024-7027.

(16) Djukic, J.-P.; Boulho, C.; Sredojevic, D.; Scheeren, C.; Zaric, S.; Ricard, L.; Pfeffer, M. The Stereospecific Ligand Exchange at a Pseudo-Benzylic T-4 Iridium Centre in Planar-Chiral Cycloiridium ( $\eta^{6}$-Arene)tricabonylchromium Complexes. Chem. Eur. J. 2009, 15, 10830-10842.

(17) Gaussian 09, Revision C.o1, Frisch, M. J.; Trucks, G. W.; Schlegel, H. B.; Scuseria, G. E.; Robb, M. A.; Cheeseman, J. R.; Scalmani, G.; Barone, V.; Mennucci, B.; Petersson, G. A.; Nakatsuji, H.; Caricato, M.; Li, X.; Hratchian, H. P.; Izmaylov, A. F.; Bloino, J.; Zheng, G.; Sonnenberg, J. L.; Hada, M.; Ehara, M.; Toyota, K.; Fukuda, R.; Hasegawa, J.; Ishida, M.; Nakajima, T.; Honda, Y.; Kitao, O.; Nakai, H.; Vreven, T.; Montgomery, Jr., J. A.; Peralta, J. E.; Ogliaro, F.; Bearpark, M.; Heyd, J. J.; Brothers, E.; Kudin, K. N.; Staroverov, V. N.; Kobayashi, R.; Normand, J; Raghavachari, K.; Rendell, A.; Burant, J. C.; Iyengar, S. S.; Tomasi, J.; Cossi, M.; Rega, N.; Millam, J. M.; Klene, M.; Knox, J. E.; Cross, J. B.; Bakken, V.; Adamo, C.; Jaramillo, J.; Gomperts, R.; Stratmann, R. E.; Yazyev, O.; Austin, A. J.; Cammi, R.; Pomelli, C.; Ochterski, J. W.; Martin, R. L.; Morokuma, K.; Zakrzewski, V. G.; Voth, G. A.; Salvador, P.; Dannenberg, J. J.; Dapprich, S.; Daniels, A. D.; Farkas, Ö.; Foresman, J. B.; Ortiz, J. V.; Cioslowski, J.; Fox, D. J.; Gaussian, Inc., Wallingford CT, USA, 2009.

(18) Wadt, W. R.; Hay, P. J. Ab initio Effective Core Potentials for Molecular Calculations. Potentials for Main Group Elements Na to Bi. J. Chem. Phys. 1985, 82, 284-298.

(19) Doux, M.; Ricard, L.; Le Floch, P.; Jean, Y. Addition of Hz on (Sulfur, Phosphorus, Sulfur)-Pincer-Based Rhodium(I), Iridium (I), Palladum(II), and Platinum(II) Complexes: Reactivity and Regioselectivity. Organometallics 2006, 25, 1101-1111.

(20) Gil-Ramírez, G.; Escudero-Adán, E. C.; Benet-Buchholz, J.; Ballester, P. Quantitative Evaluation of Anion- $\pi$ Interactions in Solution. Angew. Chem. Int. Ed. 2008, 47, 4114-4118.

(21) Sammakia, T.; Latham, H. A.; Schaad, D. R. Highly Diastereoselective Ortho Lithiations of Chiral OxazolineSubstituted Ferrocenes. J. Org. Chem. 1995, 6o, 10-11.

(22) Arthurs, R. A.; Horton, P. N.; Coles, S. J.; Richards, C. J. Stereoselective and Stereospecific Reactions of Cobalt Sandwich Complexes: Synthesis of a New Class of Single Enantiomer Bulky Planar Chiral P-N and P-P Ligands. Chem. Eur. J. 2018, 24, 43104319.

(23) Programs CrysAlisPro, Oxford Diffraction Ltd., Abingdon, UK (2010). 